Article

\title{
Genetic Dissection of Grain Nutritional Traits and Leaf Blight Resistance in Rice
}

\author{
Gwen Iris Descalsota-Empleo ${ }^{1,2}$, Abd Aziz Shamsudin Noraziyah ${ }^{3}$, Ian Paul Navea ${ }^{1,4}$, \\ Chongtae Chung ${ }^{5}$, Maria Stefanie Dwiyanti $1,6{ }^{\mathbb{C}}$, Reuben Jacob Dicen Labios ${ }^{1}$, \\ Asmuni Mohd Ikmal ${ }^{3}{ }^{\circledR}$, Venice Margarette Juanillas ${ }^{1}{ }^{\circledR}$, Mary Ann Inabangan-Asilo ${ }^{1}$, \\ Amery Amparado ${ }^{1}$, Russell Reinke ${ }^{1}$, Casiana M. Vera Cruz ${ }^{1}$, Joong Hyoun Chin ${ }^{7, *}$ and \\ B.P. Mallikarjuna Swamy ${ }^{1, *}$
}

1 International Rice Research Institute (IRRI), Laguna 4031, Philippines; gidescalsota@gmail.com (G.I.D.-E.); ipnavea@gmail.com (I.P.N.); dwiyanti@abs.agr.hokudai.ac.jp (M.S.D.); jacob.labios@gmail.com (R.J.D.L.); v.juanillas@irri.org (V.M.J.); m.inabangan@irri.org (M.A.I.-A.); a.amparado@irri.org (A.A.); r.reinke@irri.org (R.R.); c.veracruz@irri.org (C.M.V.C.)

2 University of the Southern Mindanao, Kabacan, Cotabato 9407, Philippines

3 Faculty of Science and Technology, Universiti Kebangsaan Malaysia, 43600 Bangi, Selangor, Malaysia; nora_aziz@ukm.edu.my (A.A.S.N.); mohdikmal@siswa.ukm.edu.my (A.M.I.)

4 Nousbo Corp. \#4-107, 89 Seohoro, Gwonsun, Suwon 16614, Gyeonggi, Korea

5 Chungcheongnam-do Agricultural Research and Extension Services, 167, Chusa-ro, Shinam-myeon, Yesan-gun 32418, Chungcheongnam-do, Korea; chts6991@korea.kr

6 Applied Plant Genome Laboratory, Hokkaido University, Kita 9, Nishi 9, Kita-ku, Sapporo 060-8589, Japan

7 Department of Integrative Bio-Industrial Engineering, Sejong University, 209, Neungdong-ro, Gwangjin-gu, Seoul 05006, Korea

* Correspondence: jhchin@sejong.ac.kr (J.H.C.); m.swamy@irri.org (B.P.M.S.); Tel.: +63-2-580-5600 (ext. 2739) (J.H.C.); +82-2-3408-3897 (B.P.M.S.)

Received: 17 November 2018; Accepted: 28 December 2018; Published: 8 January 2019

\begin{abstract}
Colored rice is rich in nutrition and also a good source of valuable genes/quantitative trait loci (QTL) for nutrition, grain quality, and pest and disease resistance traits for use in rice breeding. Genome-wide association analysis using high-density single nucleotide polymorphism (SNP) is useful in precisely detecting QTLs and genes. We carried out genome-wide association analysis in 152 colored rice accessions, using 22,112 SNPs to map QTLs for nutritional, agronomic, and bacterial leaf blight (BLB) resistance traits. Wide variations and normal frequency distributions were observed for most of the traits except anthocyanin content and BLB resistance. The structural and principal component analysis revealed two subgroups. The linkage disequilibrium (LD) analysis showed $74.3 \%$ of the marker pairs in complete LD, with an average LD distance of $1000 \mathrm{~kb}$ and, interestingly, $36 \%$ of the $\mathrm{LD}$ pairs were less than $5 \mathrm{~Kb}$, indicating high recombination in the panel. In total, 57 QTLs were identified for ten traits at $p<0.0001$, and the phenotypic variance explained (PVE) by these QTLs varied from 9\% to 18\%. Interestingly, 30 (53\%) QTLs were co-located with known or functionally-related genes. Some of the important candidate genes for grain Zinc (Zn) and BLB resistance were OsHMA9, OsMAPK6, OsNRAMP7, OsMADS13, and OsZFP252, and Xa1, $\mathrm{Xa3}, x a 5, x a 13$ and $x a 26$, respectively. Red rice genotype, Sayllebon, which is high in both $\mathrm{Zn}$ and anthocyanin content, could be a valuable material for a breeding program for nutritious rice. Overall, the QTLs identified in our study can be used for QTL pyramiding as well as genomic selection. Some of the novel QTLs can be further validated by fine mapping and functional characterization. The results show that pigmented rice is a valuable resource for mineral elements and antioxidant compounds; it can also provide novel alleles for disease resistance as well as for yield component traits. Therefore, large opportunities exist to further explore and exploit more colored rice accessions for use in breeding.
\end{abstract}


Keywords: colored rice; nutritional content; Fe; Zn; anthocyanin; bacterial leaf blight; genome-wide association mapping; QTLs

\section{Introduction}

Rice, being a dominant cereal and staple food, provides energy and nutrition for a majority of the Asian population [1]. In general, white rice is consumed as a major part of the daily diet, which is low in nutritional value in comparison with brown rice or pigmented rice [2]. However, because of increased health consciousness in recent years, there has been a greater awareness among the general population of the health and nutritional benefits of brown rice or pigmented rice. As a result, demand has increased for colored rice and its by-products from food, health, and cosmetic industries, which has created market and export opportunities for the major rice-growing countries in Asia [3-6].

It is well known that colored rice is rich in proteins, vitamins, minerals, fiber, and also phytochemicals such as tocopherols, tocotrienols, $\delta$-oryzanols, phenolic compounds, etc., which offer several health and nutritional benefits [7-10]. Hence, many efforts have been made to promote brown rice and traditional rice varieties and also to enrich the nutritional value of modern rice varieties [11-13]. Among the different elements, Fe and $\mathrm{Zn}$ and anthocyanin-related antioxidant compounds are essential for normal growth and development and leading a healthy life [7,8]. It has been reported that more than one-third of the human population globally is affected by Fe and $\mathrm{Zn}$ deficiency, malnutrition, and oxidative stress-related health problems [14,15]. Fe deficiency causes anemia and poor immunity and cognitive development, along with higher maternal and pre-natal mortalities [16-18]. Zn deficiency results in diarrhea, stunting, poor cognitive development, low fertility, anorexia, etc. [17]; whereas oxidative stress causes several health problems such as stroke, psoriasis, dermatitis, and rheumatoid arthritis [19]. These health and nutritional problems have to be addressed urgently in order to achieve sustainable development goals by reducing the mortality of children and women, and improving people's general health by providing a nutritious diet. Thus, $\mathrm{Fe}, \mathrm{Zn}$, and antioxidant compounds have been prioritized for their enrichment in staple foods through biofortification $[18,20,21]$.

Most of the traditional landraces and wild rice accessions are pigmented and these accessions constitute a significant proportion of rice gene banks. Additionally, pigmented rice cultivars, with red, purple, black, brown and yellow kernels, are still grown in some areas in Asia because of their nutritional and medicinal value or as part of traditional cultural practices [22-25]. This germplasm can be a good source of valuable genes / quantitative trait locis (QTLs) for various nutrition, grain quality, and pest and disease resistance traits for rice breeding programs [4,26-31]. Several studies on the characterization of colored rice for different antioxidant compounds, vitamins, and minerals have shown wide variations and these accessions were found to have 3- to 4-fold higher nutrient content than modern rice varieties [32-35]. Similarly, the natural variation for bacterial leaf blight (BLB) resistance in the colored rice can be used for breeding BLB resistance in rice. BLB is one of the most devastating diseases and causes significant yield losses in rice. BLB resistance is an integral part of all the breeding programs including breeding for biofortified rice varieties. Therefore, the evaluation of rice accessions for high Fe and $\mathrm{Zn}$ content and BLB resistance is vital in facilitating efforts to develop rice varieties with increased nutritional content.

Traditional rice varieties often possess beneficial QTLs or genes for plant improvement that are not available in current cultivated mega-varieties. Several useful QTLs in traditional varieties were identified and used by introgression or pyramiding into cultivars to improve agronomic performance [4,26-31]. Understanding the genetic basis of complex traits through the identification of major-effect QTLs/genes, and their application through maker-assisted breeding, is an attractive option to develop nutritious rice varieties. A candidate gene $(\mathrm{Pb})$ on chromosome 4 has been identified for purple pericarp in rice [36]. In an association analysis, QTLs were detected for pericarp color on chromosomes 4 and 8 [37]. Similarly, in a panel of landraces, loci were detected for pericarp color on chromosomes 2, 7, and 8 [38]. A total 
of 21 QTLs were detected for proanthocyanin and anthocyanin pigments in a recombinant inbred iines RIL population [39]. Similarly, for grain Zn, several major-effect and consistent QTLs have been reported [33,40,41]. However, genome-wide association studies (GWAS), using high-density single nucleotide polymorphism (SNP) genotyping in natural populations, are an effective way to identify more precise QTLs or genes.

A diversity panel of colored rice accessions from South Korea was evaluated at International Rice Research Institute (IRRI), Philippines, and Chungcheongnam-do, South Korea. This present study was undertaken to identify QTLs for agronomic, micronutrient, and bacterial leaf blight resistance traits using a colored rice diversity panel, a shortlist of candidate genes, and the identification of promising genotypes with desirable traits.

\section{Materials and Methods}

\subsection{Plant Materials}

A diversity panel of colored rice composed of 156 accessions was evaluated in two environments, Chungcheongnam-do, South Korea, and the Robert Zeigler Experiment Station (ZES) at the IRRI, Los Baños (LB), Laguna, Philippines. The trials were laid out in a randomized complete block design (RCBD). Standard agronomic practices and plant protection measures were applied to ensure good crop growth and complete grain development.

\subsection{Phenotyping}

All the accessions were phenotyped for nine agronomic traits, days to heading (DH), number of panicles (NP), panicle length (PL), number of spikelets per panicle (NSP), ripening ratio (RR), grain length (GL); grain width (GW), thousand-grain weight (TGW), and anthocyanin (AC) in Korea, and for DH, TGW, Fe, and Zn at the IRRI. Materials were also screened for 14 Xanthomonas oryzae pv. oryzae (Xoo) strains for BLB resistance. All the agronomic traits were measured following the IRRI Standard Evaluation System [42]. RR is the ratio of the number of filled spikelets to the total number of spikelets. We measured $\mathrm{Fe}$ and $\mathrm{Zn}$ for all the entries and from all the replications. From each replication, $50 \mathrm{~g}$ of seeds were dehulled and polished for $60 \mathrm{~s}$ (Indo Plast), and $3 \mathrm{~g}$ of milled rice samples underwent X-ray fluorescence analysis using a Bruker S2 Ranger. Per sample, two readings were collected and the values were expressed in milligrams per kilogram $(\mathrm{mg} / \mathrm{kg})$. Anthocyanin content was estimated using high performance liquid chromatography (HPLC) as described in [43].

\subsection{BLB Screening Method}

The different Xoo strains were inoculated separately to screen for disease reactions among the 156 accessions. Leaves of each accession were clip-inoculated at maximum tillering stage. Three plants per accession per strain were inoculated with bacterial suspension containing $1 \times 10^{9} \mathrm{CFU} / \mathrm{mL}$ of distilled water. Fourteen days after inoculation, the lesion length from each inoculated leaf was recorded. Lesion length was obtained by measuring the necrotic area from the point of inoculation up to the water-soaked part of the lesion. The average lesion was used for the further statistical analysis.

\subsection{Analysis of Phenotypic Data}

All the basic statistical parameters for different traits were analyzed using STAR v.2.0.1. Analysis of variance (ANOVA) and correlation estimation were carried out using PB Tools v1.4.

\subsection{Genotypic Analysis and GWAS}

DNA extraction from leaf tissues was performed using cetyl trimethyl ammonium bromide (CTAB) method. The quality and quantity of DNA was checked and normalized to $10 \mathrm{ng} / \mathrm{uL}$. A 384-plex genotype-by-sequencing (GBS) library was prepared using the ApeKI restriction enzyme, following the protocol described in Elshire et al. (2011) [44]. The quantity and quality of the GBS library was assessed 
using the Bioanalyzer kit (Agilent Genomics, Santa Clara, CA, USA). Library sequencing was performed using paired-end sequencing ( $150 \mathrm{bp}$ reads) of one 384-plex library per flow cell channel. Sequencing was performed on a HiSeq2000 (Macrogen Inc., Seoul, Korea). A total of 29,194,089 paired-end reads, each with a length of 101 base pairs (bp), were generated. The raw sequence reads were filtered based on the following criteria: (1) the sequence reads perfectly match one of the barcodes with the expected ApeKI cut site four-base remnant (CWGC), and (2) does not contain " $\mathrm{N}$ " within the first 64 bases after the barcode. Using the barcodes, the raw reads were processed and collapsed into sets of unique 64-bp sequence tags, which were then aligned to the Nipponbare reference genome (IRGSP 1.0) using Burrows-Wheeler Aligner (BWA) software. SNP calling was done using TASSEL-GBS plugin [45] in TASSEL version 3.0.147 [46]. SNP marker data of 157 genotypes, generated by GBS, consisting of 180,599 SNPs, were screened based on $\geq 80 \%$ call rate, locus homozygosity, and minor allele frequency (MAF) $\geq 0.05$, which resulted in $22,112 \mathrm{SNPs}$. However, one accession had greater than $50 \%$ missing rate and had to be excluded from the analysis. We used phenotypic and genotypic data from 152 accessions for further analysis (Table S1). This set of SNPs was used to analyze the intra-chromosomal linkage disequilibrium (LD) ( $\mathrm{r}^{2}$ values) between SNP marker pairs, which was calculated using TASSEL v5.2.20 with $50 \mathrm{LD}$ windows. Marker pairs with statistically significant $\operatorname{LD}(p<0.05)$ were considered in the LD analysis. An LD map was generated by plotting $\mathrm{r}^{2}$ values against distance $(\mathrm{Mb})$ using Graphical GenoTypes (GGTPLOT2) [47]. Population structure was determined using all the SNP markers. The number of groups (K) tested varied from 1 to 10 , and each $\mathrm{K}$ structure of the population was analyzed with three replications. Each run included a burn-in period of 10,000 steps and 10,000 Monte Carlo Markov Chain iterations. The number of groups $(K)$ was estimated using $(\Delta K)[48]$ in Structure Harvester $[48,49]$. The average trait values of each accession were used for association analysis. The mixed linear model with kinship [MLM (Q+K)] approach in Genome Association Prediction Integrated Tool (GAPIT) was used to carry out GWAS. Manhattan plots were produced and a threshold value of $-\log (p$ value $) \geq 3.0$ was used to declare significant marker-trait associations.

\subsection{Candidate Gene Analysis}

The physical position of peak SNP markers for each QTL was determined and used for candidate gene search. Annotated genes and gene families with their functions related to the respective traits were downloaded from Oryzabase (https: / / shigen.nig.ac.jp/rice/oryzabase/gene) and the physical positions of annotated genes with known functions were determined using the Rice Annotation Project - Data Base RAP DB Genome Browser (http:/ / rapdb.dna.affrc.go.jp/viewer/gbrowse/irgsp1). Further searches were performed for previously reported QTLs that co-localized with present QTLs using the Gramene database.

\section{Results}

\subsection{Phenotypic Analysis}

The traits DH, NP, PL, TGW, Fe, and Zn were normally distributed, whereas RR and AC showed skewed distribution (Figure 1). The colored rice panel showed wide variations for all the traits. Table 1 provides the range, mean, and co-efficient of variation for different traits in the respective environments. The colored rice accessions Bir-R-Ton-Tsan and Chenlun (Hea-Li) 55 were early for DH; Akuramboda and CN09 had the highest Zn (26.5 mg/Kg); French Type and Chenlun (Hea-Li) 55 had the highest value for $\mathrm{Fe}(2.3 \mathrm{mg} / \mathrm{Kg})$, along with Ase Pindjauand Khao Kam for AC, Akuramboda and Pulut Hitam for NP, Paro Lo'ting and Tadong1 for PL, Mah Nam Pui and Ketan Mari Kangen for NSP, DNJ51 and ARC6577 for RR, and Khao and Khao' Bam for TGW (Table S1). Coefficients of variation (CV) for all traits varied from $12.0 \%$ to $40.2 \%$. Three traits (DH, PL, and TGW) showed a medium CV (10-20\%) and two traits (NSP and RR) showed a very high CV (>30\%); whereas NP and the two micronutrient traits ( $\mathrm{Zn}$ and $\mathrm{Fe}$ ) had high CV (20-30\%). In general, six accessions had grain $\mathrm{Zn}$ of $25 \mathrm{mg} / \mathrm{Kg}$ or more, ten accessions had grain Fe of more than $2 \mathrm{mg} / \mathrm{Kg}$, and eight accessions had more than $250 \mathrm{mg} / 100 \mathrm{~g}$ for anthocyanin content. The anthocyanin was in the range of 94.70-202.46 mg Cy-3-glc/100 g db in Indonesian pigmented rice [50]. 


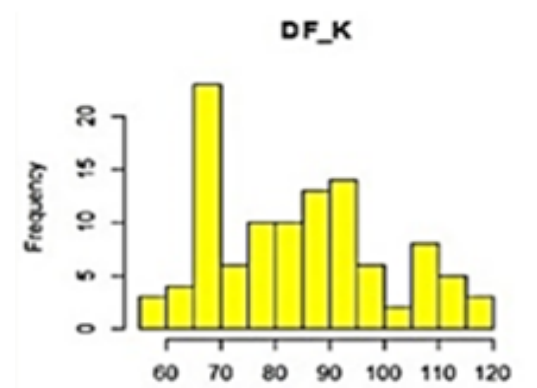

Days

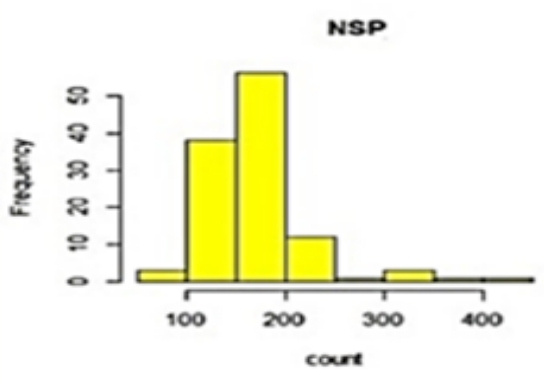

RR

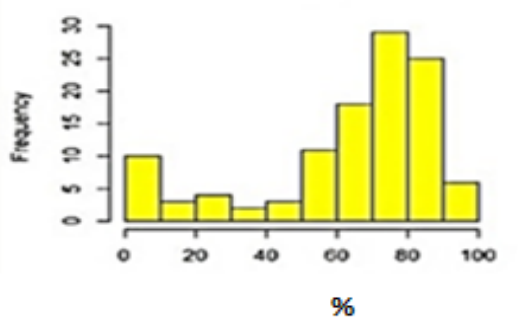

PF_

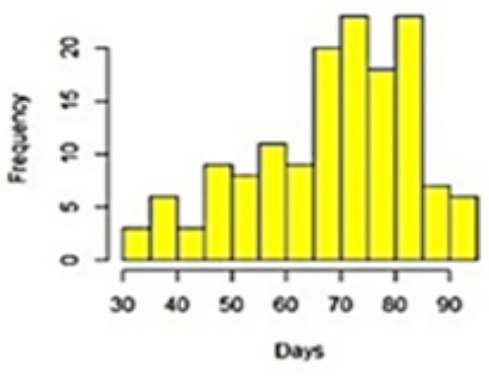

TOW_K
NP

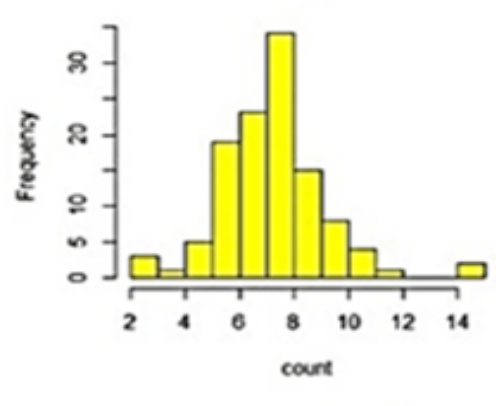

Tow_l

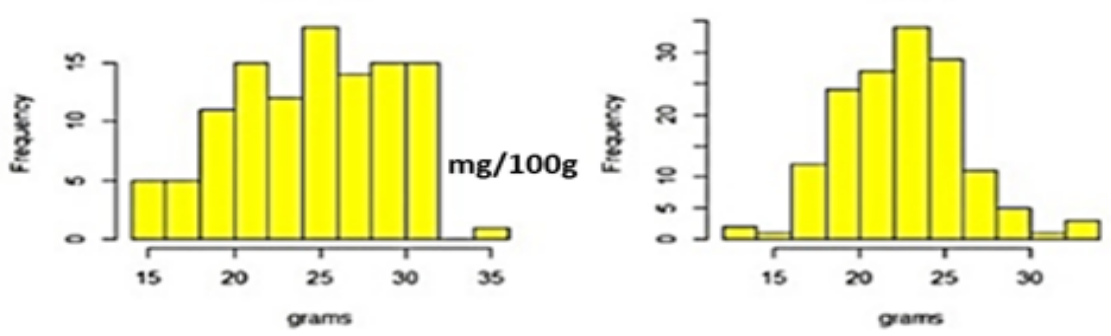

Ante
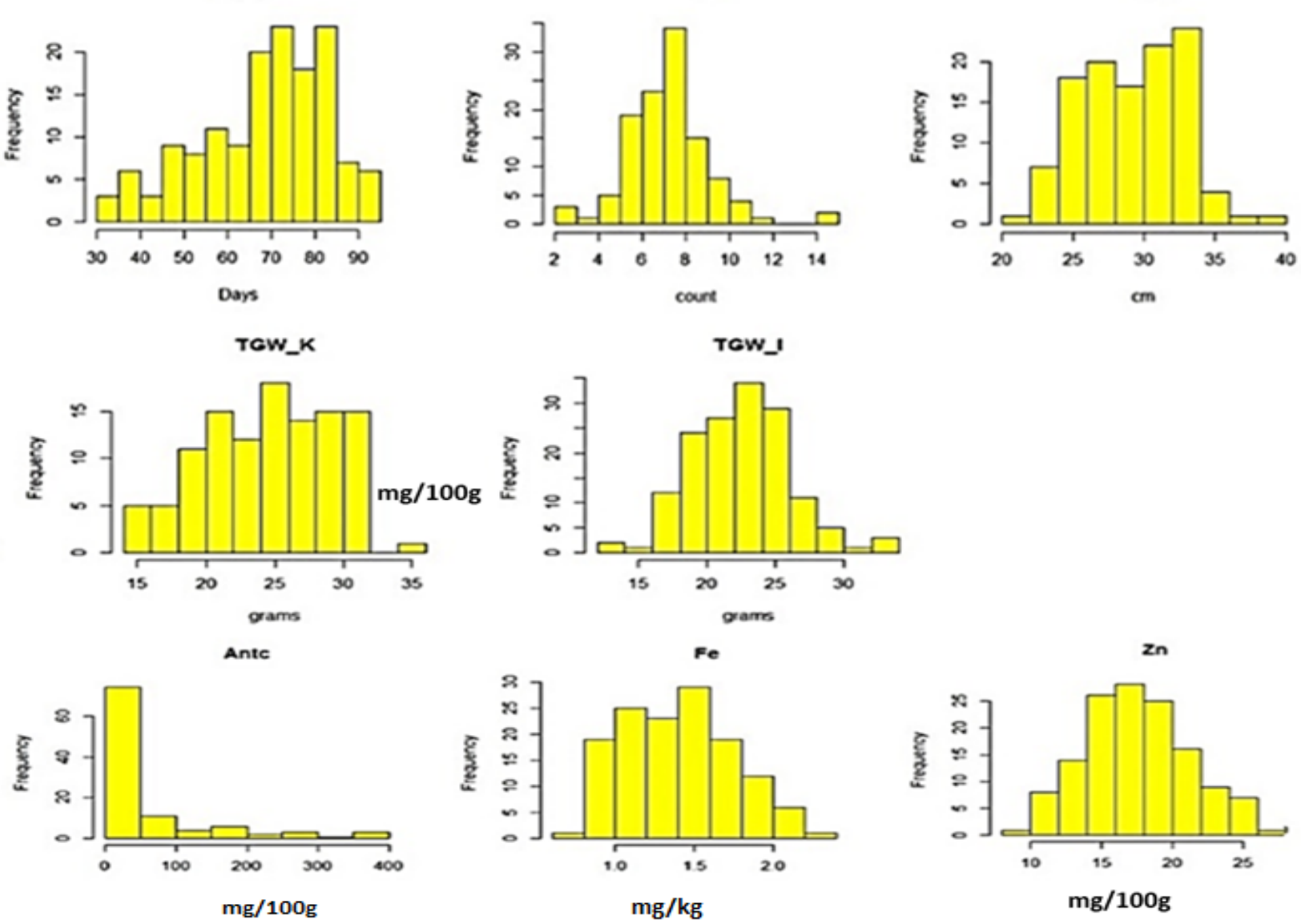

Figure 1. Histograms for agronomic and micronutrient traits. 
Table 1. Descriptive statistics of agronomic and micronutrient traits in colored rice.

\begin{tabular}{ccccc}
\hline Trait & Range & Mean \pm SE & CV (\%) & Location \\
\hline DH & $58-119$ & $84.51 \pm 1.49$ & 18.2 & $\mathrm{~K}$ \\
& $34-94$ & $68.94 \pm 1.21$ & 21.2 & $\mathrm{I}$ \\
NP & $2-15$ & $7.47 \pm 0.18$ & 26.3 & $\mathrm{~K}$ \\
PL & $21.5-40.0$ & $29.39 \pm 0.33$ & 12.0 & $\mathrm{~K}$ \\
NSP & $70.5-406.0$ & $171.73 \pm 4.86$ & 30.3 & $\mathrm{~K}$ \\
RR & $0.2-93.6$ & $63.32 \pm 2.42$ & 40.2 & $\mathrm{~K}$ \\
GL & $0.48-0.75$ & $0.63 \pm 0.0056$ & 9.03 & $\mathrm{~K}$ \\
GW & $0.21-0.33$ & $0.26 \pm 0.0025$ & 9.75 & $\mathrm{~K}$ \\
TGW & $14.2-34.6$ & $24.62 \pm 0.44$ & 18.7 & $\mathrm{~K}$ \\
& $13.4-32.9$ & $22.51 \pm 0.29$ & 15.8 & $\mathrm{I}$ \\
AC & $0.8-375.4$ & $57.33 \pm 8.92$ & - & $\mathrm{K}$ \\
Zn & $9.2-26.6$ & $17.56 \pm 0.31$ & 20.7 & $\mathrm{I}$ \\
Fe & $0.7-2.3$ & $1.41 \pm 0.03$ & 25.5 & $\mathrm{I}$ \\
\hline
\end{tabular}

$\mathrm{DH}=$ days to heading; $\mathrm{PH}=$ plant height $(\mathrm{cm}), \mathrm{NP}=$ number of panicles; $\mathrm{PL}=$ panicle length $(\mathrm{cm}) ; \mathrm{NSP}=$ number of spikelets per panicle; $\mathrm{RR}=$ ripening ratio; $\mathrm{GL}=$ grain length; $\mathrm{GW}=$ grain width; $\mathrm{TGW}$ = thousand-grain weight (g); AC = anthocyanin content (mg/100 g); $\mathrm{Zn}=$ zinc $(\mathrm{mg} / \mathrm{kg}) ; \mathrm{Fe}=$ iron $(\mathrm{mg} / \mathrm{kg}) ; \mathrm{K}=$ Korea; I = IRRI, Philippines.

The accessions showed wide variations in response to 14 different Xoo strains. The disease score measured as lesion length (LL) showed skewed distributions. The lesion length in response to Xoo strains PXO61 and PXO339 showed the widest and narrowest LL variation, respectively. Figure 2 shows the correlation among the traits. Of the 36 possible correlations among all traits evaluated in both environments, a total of 17 were significant; three of them were positively correlated and 11 were negatively correlated. DH was negatively correlated with NP, RR, and TGW, but positively correlated with NSP; NP was negatively correlated with PL, NSP, and AC; PL was positively associated with NSP and AC; NSP was negatively correlated with RR and TGW; RR was positively associated with TGW, but negatively with AC; and TGW was negatively associated with AC. Similarly, Fe and Zn were negatively correlated with $\mathrm{DH}$ and $\mathrm{Fe}$, and $\mathrm{Zn}$ had a highly significant positive correlation.

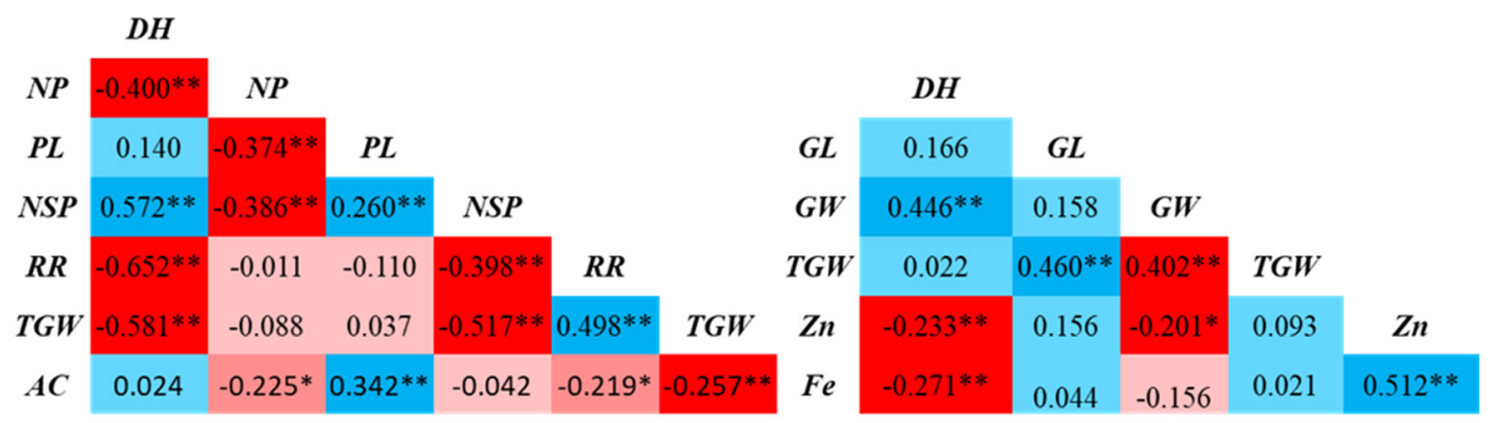

Figure 2. Correlation among different traits evaluated at two different locations.

\subsection{Genetic Analysis and Linkage Mapping}

GBS data were aligned with the reference genome Nipponbare and SNPs were called. A total of 22,112 SNP markers (with average density of $19.4 \mathrm{~kb}$ ) covering all 12 chromosomes were used to access the genetic structure of the 152 rice accessions. The number of SNPs on each chromosome varied from 1219 on chromosome 12 to 3315 on chromosome 1 . All the other chromosomes had more than 1400 SNPs each. The magnitude of LD and its decay with genetic distance determine the resolution of association mapping. The LD analysis in the colored rice panel identified 809,803 pairs $(74.3 \%)$ in complete LD (Table 2). The shortest physical distance group $(0-5 \mathrm{~kb})$ had the highest average LD (0.653). The decay declined to 0.340 average LD ( $48 \%$ decline) at a physical distance of $>750$ to $1000 \mathrm{bp}$, before it increased at a distance of more than $1000 \mathrm{~kb}$ (Figure 3). In addition, the same pattern was 
observed for the percentage of marker pairs in complete LD, for which it decreased from $36.5 \%$, in the shortest distance group, to $1.7 \%$ at a physical distance of $>750$ to $1000 \mathrm{bp}$.

Table 2. Linkage disequilibrium (LD) in the colored rice panel.

\begin{tabular}{ccccc}
\hline Distance (kb) & $\begin{array}{c}\text { Average LD } \\
(\boldsymbol{p}<\mathbf{0 . 0 5}) \mathbf{r}^{\mathbf{2}}\end{array}$ & $\begin{array}{c}\text { Significant LD } \\
\text { Pairs }\end{array}$ & $\begin{array}{c}\text { Marker Pairs in } \\
\text { LD }\end{array}$ & $\begin{array}{c}\text { Marker Pairs in LD (\%) } \\
\text { per Distance Group }\end{array}$ \\
\hline $0-5$ & 0.653 & 19,394 & 7077 & 36.49 \\
$>5-100$ & 0.491 & 117,154 & 12,783 & 10.91 \\
$>100-250$ & 0.409 & 164,039 & 7264 & 4.43 \\
$>250-500$ & 0.361 & 242,032 & 5408 & 2.23 \\
$>500-750$ & 0.341 & 160,178 & 2531 & 1.58 \\
$>750-1000$ & 0.340 & 63,238 & 1133 & 1.79 \\
$>1000$ & 0.383 & 43,048 & 2151 & 5.00 \\
Total & - & 809,803 & 38,347 & - \\
\hline
\end{tabular}

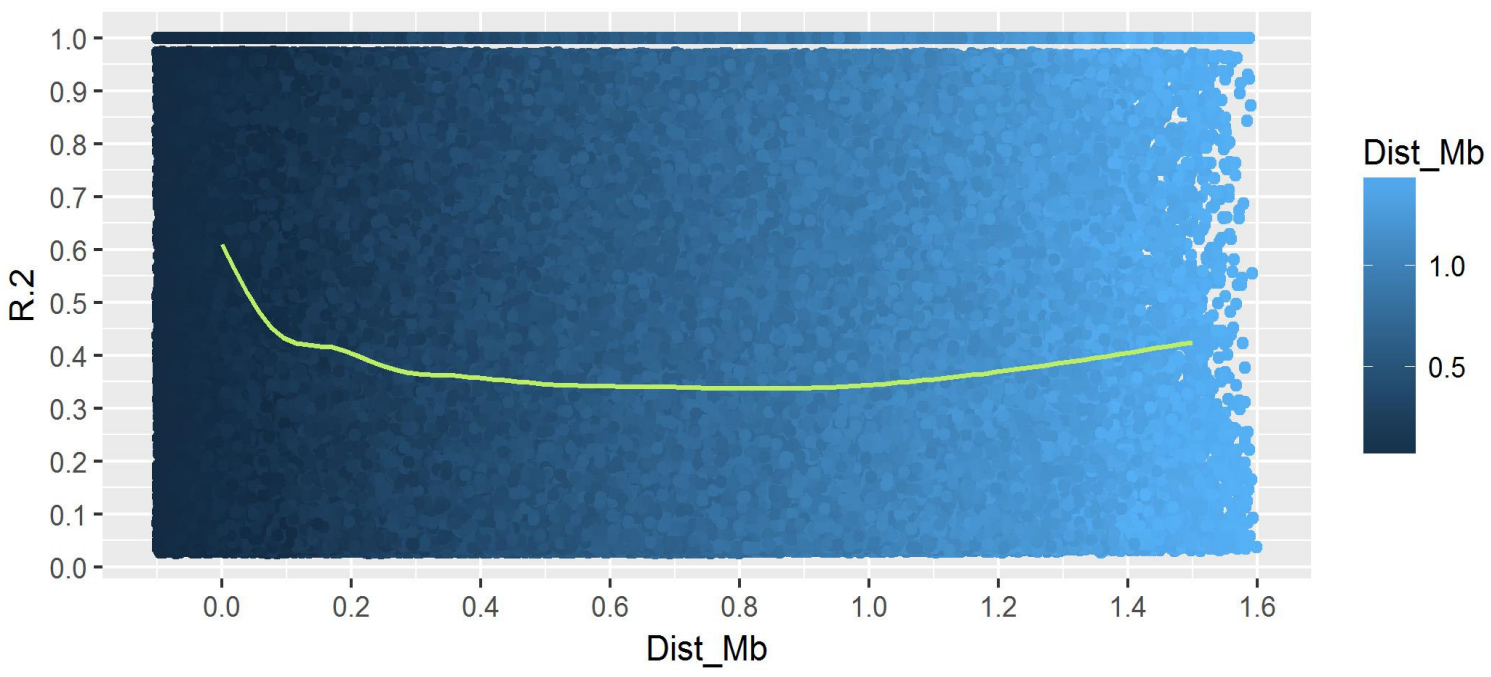

Figure 3. LD decay in the colored rice panel using 22,112 markers.

\subsection{Structure and Principal Component Analysis}

Population structure analysis, using a subset of SNP markers, revealed that the variance of $\log$ likelihood increased from $\mathrm{K}=1$ to $\mathrm{K}=10$, and the highest $\Delta \mathrm{K}$ of 3762.2 was observed at $\mathrm{K}=2$ (Figure $4 a, b)$, indicating that the population can be divided into two subgroups with 114 and 42 individuals belonging to clusters 1 and 2, respectively. The cluster memberships of each individual (Q1) and kinship data for all traits were used for GWAS. These varieties were assigned to three genetic clusters in a three-dimensional plot of the first three principal components (i.e., PC1, PC2, and PC3). Using a three-dimensional (3D) scatter plot of principal component analysis (PCA), and based on 22,121 SNPs, two major clusters were clearly distinguished among all the colored rice accessions (Figure 5), which is consistent with results from population structure analysis as it also grouped the accessions into two subgroups. Rice genotypes from cluster 1 were depicted by red color, whereas cluster 2 genotypes were represented by black color. The first three PCs accounted for $45 \%$ of the total variance breakdown of this cumulative variance value, which revealed contributions of $35 \%, 6 \%$, and $4 \%$ for PC1, PC2, and PC3, respectively. 


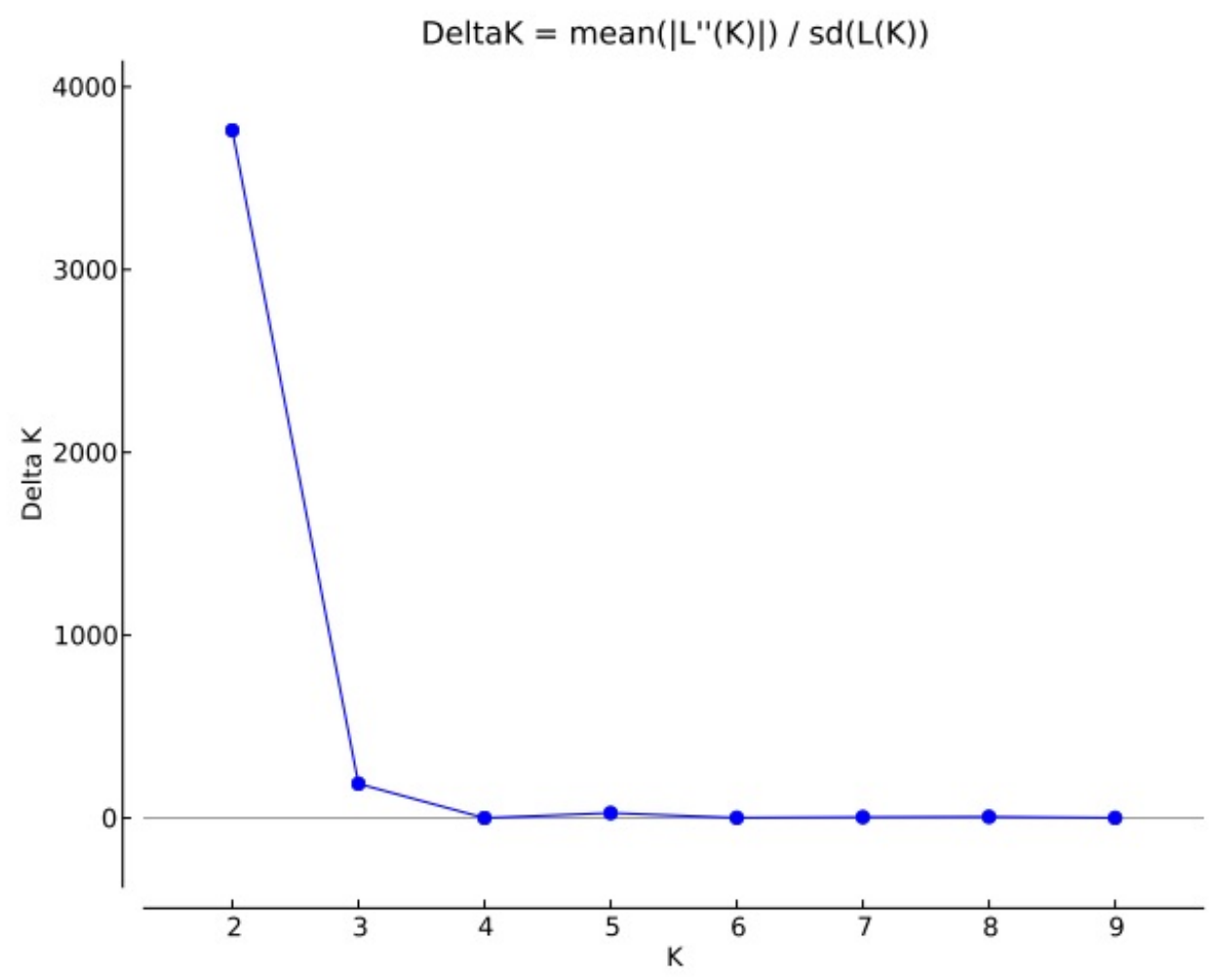

(a)

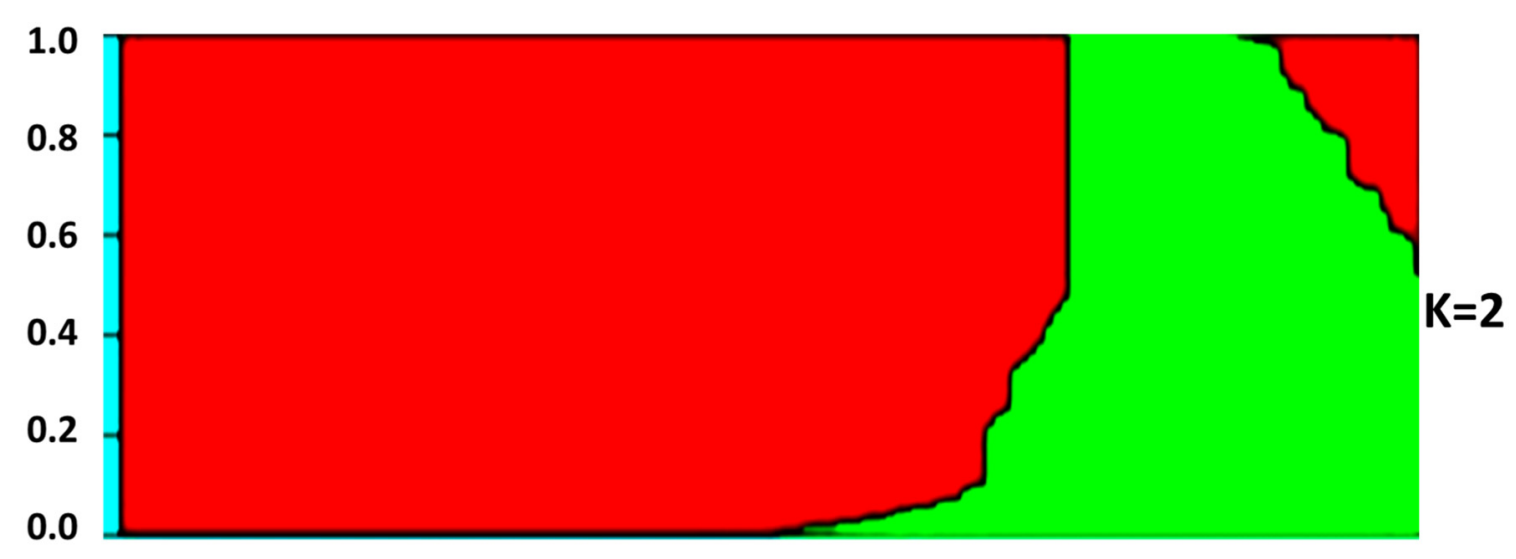

(b)

Figure 4. (a) Population structure in the colored rice panel. (b) Bar plot representing the cluster membership of each accession detected by structure. 


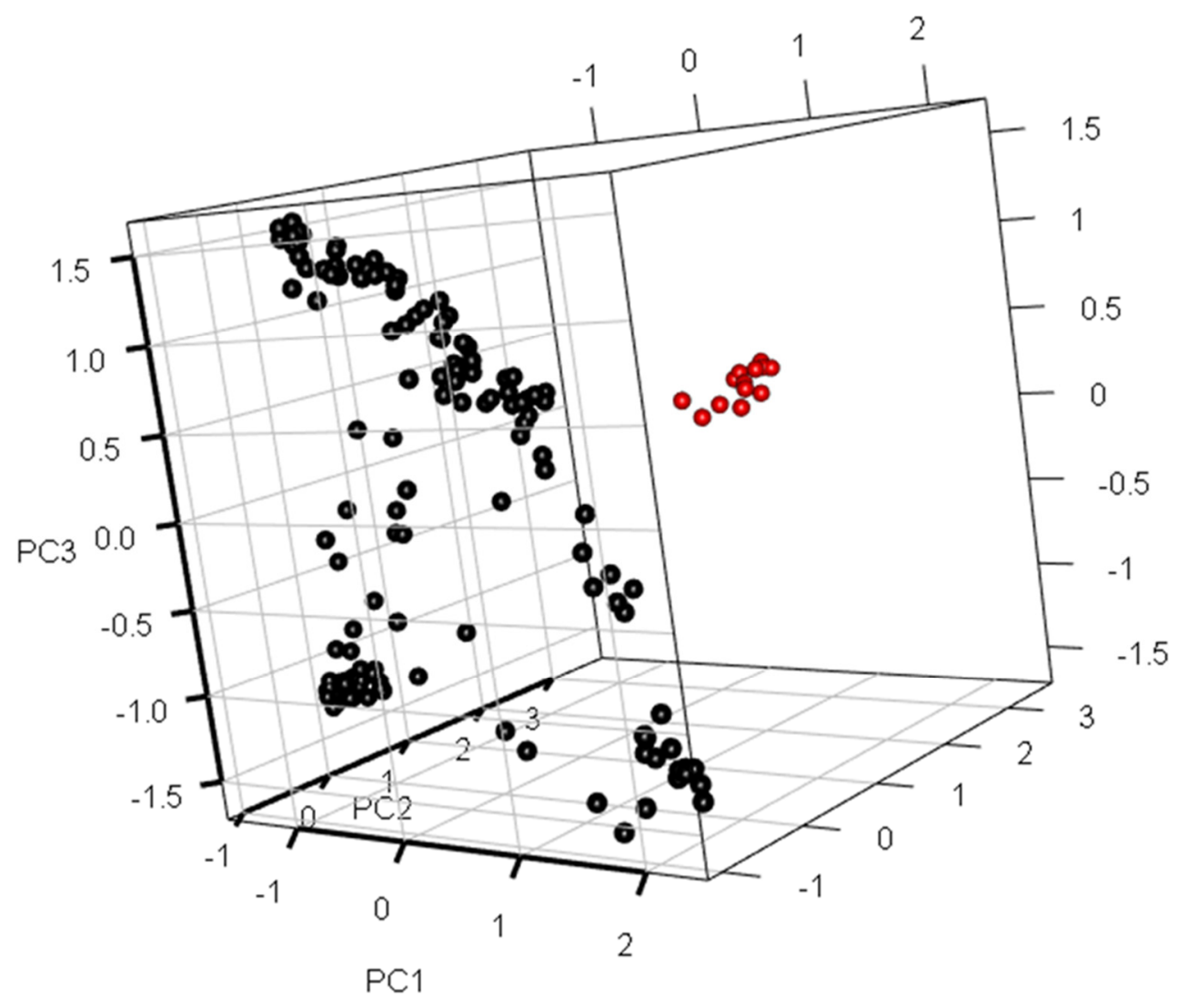

Figure 5. 3D scatter plot of the first three principal component analysis (PCA).

\subsection{Genome-Wide Association Mapping}

In total, 35 QTLs were identified for agronomic and nutritional traits at $p<0.0001$ (Table 3 and Figure 6). They were distributed on all the chromosomes, except on chromosome 7 , and the phenotypic variance explained (PVE) of these QTLs varied from 9\% to 18\%. The highest number of QTLs was identified on chromosome 1 (seven), followed by chromosomes 6 and 11, each with five QTLs. On other chromosomes, the number of QTLs varied from one to four. Similarly, for BLB resistance, 22 QTLs were identified on chromosomes 1, 4, 7, 8, 9, 10,11, and 12. The highest number of QTLs was identified on chromosome 1 (four), followed by chromosomes 4, 7, 8, and 9, each with three QTLs. The PVE of the QTLs varied from 9.9\% to 12.9\%. Four QTLs were identified for resistance to POX330, and three QTLs each for resistance to PXO61 and PXO99. The probability of false detection rate (FDR) estimation was non-significant for all the QTLs. Details of the QTLs identified for BLB resistance traits are provided in Table 4. 
Table 3. Quantitative trait loci (QTL) for agronomic and nutritional traits.

\begin{tabular}{|c|c|c|c|c|c|c|c|c|}
\hline Trait & QTL & Peak Marker & Chr & Position (bp) & $p$-Value & $\mathbf{R}^{2}(\%)$ & QTL & Reference \\
\hline Antc & $q A n t c_{1.1}$ & S1_33820736 & 1 & $33,820,736$ & $3.64 \times 10^{-4}$ & 14.5 & glu4a & [51] \\
\hline Antc & $q A n t c_{10.1}$ & S10_13377773 & 10 & $13,377,773$ & $4.33 \times 10^{-4}$ & 13.1 & PLA1 & [52] \\
\hline $\mathrm{DH}$ & $q D H_{1.1}$ & S1_729480 & 1 & 729,480 & $3.39 \times 10^{-4}$ & 13.3 & - & - \\
\hline $\mathrm{DH}$ & $q D H_{1.2}$ & S1_35193967 & 1 & $35,193,967$ & $4.06 \times 10^{-4}$ & 9.4 & PME1 & [53] \\
\hline $\mathrm{DH}$ & $q D H_{3.1}$ & S3_4363021 & 3 & $4,363,021$ & $3.11 \times 10^{-4}$ & 14.7 & $l s i 2$ & [54] \\
\hline $\mathrm{DH}$ & $q \mathrm{DH}_{5.1}$ & S5_14036335 & 5 & $14,036,335$ & $5.00 \times 10^{-4}$ & 9.8 & siz1 & [55] \\
\hline $\mathrm{DH}$ & $q \mathrm{DH}_{5.2}$ & S5_19759126 & 5 & $19,759,126$ & $4.14 \times 10^{-4}$ & 10.3 & - & - \\
\hline $\mathrm{DH}$ & $q \mathrm{DH}_{5.3}$ & S5_21908094 & 5 & $21,908,094$ & $4.88 \times 10^{-4}$ & 9.3 & OsLti6b & [56] \\
\hline $\mathrm{DH}$ & $q D H_{6.1}$ & S6_30059999 & 6 & $30,059,999$ & $3.63 \times 10^{-4}$ & 10.9 & OsFD2 & [57] \\
\hline $\mathrm{DH}$ & $q D H_{10.1}$ & S10_3764176 & 10 & $3,764,176$ & $3.00 \times 10^{-4}$ & 11.1 & - & - \\
\hline $\mathrm{Fe}$ & $q F e_{6.1}$ & S6_21751078 & 6 & $21,751,078$ & $5.39 \times 10^{-4}$ & 10.3 & $q F e 6$ & [58] \\
\hline $\mathrm{Fe}$ & $q F e_{12.1}$ & S12_3936500 & 12 & $3,936,500$ & $5.58 \times 10^{-4}$ & 10.6 & - & - \\
\hline GL & $q G L_{4.1}$ & S4_20409894 & 4 & $20,409,894$ & $4.79 \times 10^{-4}$ & 14.0 & GIF1 & [59] \\
\hline GW & $q G W_{1.1}$ & S1_22901457 & 1 & $22,901,457$ & $4.28 \times 10^{-4}$ & 13.3 & OsaLeg1 & [60] \\
\hline GW & $q G W_{1.2}$ & S1_40478067 & 1 & $40,478,067$ & $4.06 \times 10^{-4}$ & 12.6 & - & - \\
\hline GW & $q G W_{2.1}$ & S2_34634978 & 2 & $34,634,978$ & $7.54 \times 10^{-4}$ & 12.6 & - & - \\
\hline GW & $q G W_{6.1}$ & S6_1344933 & 6 & $1,344,933$ & $5.10 \times 10^{-4}$ & 14.4 & SSG6 & [61] \\
\hline GW & $q G W_{7.1}$ & S7_1189467 & 7 & $1,189,467$ & $3.41 \times 10^{-4}$ & 9.8 & AQED046 & [62] \\
\hline GW & $q G W_{7.2}$ & S7_27630784 & 7 & $27,630,784$ & $3.47 \times 10^{-4}$ & 12.5 & - & - \\
\hline $\mathrm{NP}$ & $q N P_{11.1}$ & S11_21353461 & 11 & $21,353,461$ & $8.86 \times 10^{-5}$ & 16.7 & - & - \\
\hline PL & $q P L_{6.1}$ & S6_30785431 & 6 & $30,785,431$ & $5.32 \times 10^{-4}$ & 12.9 & OsSSI & [63] \\
\hline PL & $q P L_{10.1}$ & S10_94178 & 10 & 94,178 & $5.32 \times 10^{-4}$ & 12.6 & - & - \\
\hline $\mathrm{RR}$ & $q R R_{1.1}$ & S1_18464561 & 1 & $18,464,561$ & $5.02 \times 10^{-4}$ & 12.0 & - & - \\
\hline $\mathrm{RR}$ & $q R R_{4.1}$ & S4_13845093 & 4 & $13,845,093$ & $3.97 \times 10^{-4}$ & 14.5 & RERJ1 & [64] \\
\hline $\mathrm{RR}$ & $q R R_{8.1}$ & S8_5478727 & 8 & $5,478,727$ & $3.15 \times 10^{-4}$ & 14.2 & - & - \\
\hline $\mathrm{RR}$ & $q R R_{10.1}$ & S10_12185948 & 10 & $12,185,948$ & $5.02 \times 10^{-4}$ & 13.2 & - & - \\
\hline RR & $q R R_{11.1}$ & S11_2918255 & 11 & $2,918,255$ & $4.85 \times 10^{-4}$ & 14.0 & - & - \\
\hline $\mathrm{RR}$ & $q R R_{11.2}$ & S11_3031310 & 11 & $3,031,310$ & $5.51 \times 10^{-4}$ & 13.6 & - & - \\
\hline $\mathrm{RR}$ & $q R R_{11.3}$ & S11_6596315 & 11 & $6,596,315$ & $3.45 \times 10^{-4}$ & 15.3 & OsCIPK15 & [65] \\
\hline $\mathrm{RR}$ & $q R R_{11.4}$ & S11_24271121 & 11 & $24,271,121$ & $9.61 \times 10^{-5}$ & 17.5 & RCN1 & [66] \\
\hline $\mathrm{Zn}$ & $q Z n_{1.1}$ & S1_6783213 & 1 & $6,783,213$ & $3.18 \times 10^{-4}$ & 11.9 & - & - \\
\hline $\mathrm{Zn}$ & $q Z n_{6.1}$ & S6_28504959 & 6 & $28,504,959$ & $8.65 \times 10^{-5}$ & 15.3 & OsHMA9, OsMAPK6 & {$[67,68]$} \\
\hline $\mathrm{Zn}$ & $q Z n_{12.1}$ & S12_5125546 & 12 & $5,125,546$ & $3.88 \times 10^{-4}$ & 12.7 & - & - \\
\hline $\mathrm{Zn}$ & $q Z n_{12.2}$ & S12_9550577 & 12 & $9,550,577$ & $9.05 \times 10^{-5}$ & 17.9 & - & - \\
\hline $\mathrm{Zn}$ & $q Z n_{12.3}$ & S12_24162402 & 12 & $24,162,402$ & $2.90 \times 10^{-4}$ & 12.4 & OsNRAMP7, mel2, ZFP252 & [69-71] \\
\hline
\end{tabular}


Table 4. Genomic regions associated with leaf blight resistance.

\begin{tabular}{|c|c|c|c|c|c|c|c|c|}
\hline Xoo Strain & QTL & Peak Marker & Chr & Position (bp) & $p$-Value & $R^{2}(\%)$ & Genes & Reference \\
\hline PXO145 & $q B L B_{1.1}$ & S1_1500065 & 1 & $1,500,065$ & $4.77 \times 10^{-4}$ & 10.2 & RLCK19/OsRLCK19 & [72] \\
\hline PXO61 & $q B L B_{1.2}$ & S1_2592129 & 1 & $2,592,129$ & $5.09 \times 10^{-4}$ & 9.9 & - & - \\
\hline PXO280 & $q B L B_{1.3}$ & S1_10892915 & 1 & $10,892,915$ & $5.20 \times 10^{-4}$ & 11.4 & - & - \\
\hline PXO341 & $q B L B_{1.4}$ & S1_22881113 & 1 & $22,881,113$ & $5.40 \times 10^{-4}$ & 9.9 & OsLOL2 & {$[73]$} \\
\hline PXO347 & $q B L B_{4.1}$ & S4_3958984 & 4 & $3,958,984$ & $5.61 \times 10^{-4}$ & 12.0 & - & - \\
\hline PXO280 & $q B L B_{4.2}$ & S4_14640816 & 4 & $14,640,816$ & $4.49 \times 10^{-4}$ & 11.4 & - & - \\
\hline PXO363 & $q B L B_{4.3}$ & S4_33881790 & 4 & $33,881,790$ & $5.55 \times 10^{-4}$ & 9.9 & OsLG1, Xa1 & [74-80] \\
\hline PXO363 & $q B L B_{5.1}$ & S5_14178355 & 5 & $14,178,355$ & $5.58 \times 10^{-4}$ & 12.7 & OsWRKY $45, x a 5$ & {$[76,77]$} \\
\hline PXO363 & $q B L B_{7.1}$ & S7_15511270 & 7 & $15,511,270$ & $4.55 \times 10^{-4}$ & 10.5 & OsPHR2, Rurm1, oscbt, xa8 & [81-84] \\
\hline PXO341 & $q B L B_{7.2}$ & S7_24896976 & 7 & $24,896,976$ & $4.32 \times 10^{-4}$ & 11.3 & - & - \\
\hline PXO363 & $q B L B_{7.3}$ & S7_29012591 & 7 & $29,012,591$ & $4.76 \times 10^{-4}$ & 11.8 & OsRLCK241, rtGA2.1,fzp & {$[72,85,86]$} \\
\hline PXO339 & $q B L B_{8.1}$ & S8_5260173 & 8 & $5,260,173$ & $5.20 \times 10^{-4}$ & 11.7 & OsGLP8 & [87] \\
\hline PXO339 & $q B L B_{8.2}$ & S8_17538523 & 8 & $17,538,523$ & $4.86 \times 10^{-4}$ & 10.6 & - & - \\
\hline PXO112 & $q B L B_{8.3}$ & S8_26167157 & 8 & $26,167,157$ & $4.38 \times 10^{-4}$ & 10.6 & $x a 13$, Os8N3 & {$[88,89]$} \\
\hline PXO99 & $q B L B_{9.1}$ & S9_4075062 & 9 & $4,075,062$ & $4.12 \times 10^{-4}$ & 11.2 & - & - \\
\hline PXO61 & $q B L B_{9.2}$ & S9_5308616 & 9 & $5,308,616$ & $5.22 \times 10^{-4}$ & 10.8 & - & - \\
\hline PXO112 & $q B L B_{9.3}$ & S9_10899580 & 9 & $10,899,580$ & $4.57 \times 10^{-4}$ & 12.9 & - & - \\
\hline PXO99 & $q B L B_{10.1}$ & S10_11388943 & 10 & $11,388,943$ & $4.49 \times 10^{-4}$ & 10.4 & - & - \\
\hline PXO79 & $q B L B_{11.1}$ & S11_4583814 & 11 & $4,583,814$ & $4.60 \times 10^{-4}$ & 10.4 & OsRLCK315 & {$[72]$} \\
\hline PXO340 & $q B L B_{11.2}$ & S11_27999035 & 11 & $27,999,035$ & $4.88 \times 10^{-4}$ & 10.4 & $\mathrm{X} a 3$ and $\mathrm{Xa26}$ & [90] \\
\hline PXO61 & $q B L B_{12.1}$ & S12_11555404 & 12 & $11,555,404$ & $4.94 \times 10^{-4}$ & 10.7 & OsRBCS3 & [91] \\
\hline PXO99 & $q B L B_{12.2}$ & S12_15461931 & 12 & $15,461,931$ & $4.96 \times 10^{-4}$ & 10.9 & PSTOL1, OsORC3 & {$[92,93]$} \\
\hline
\end{tabular}




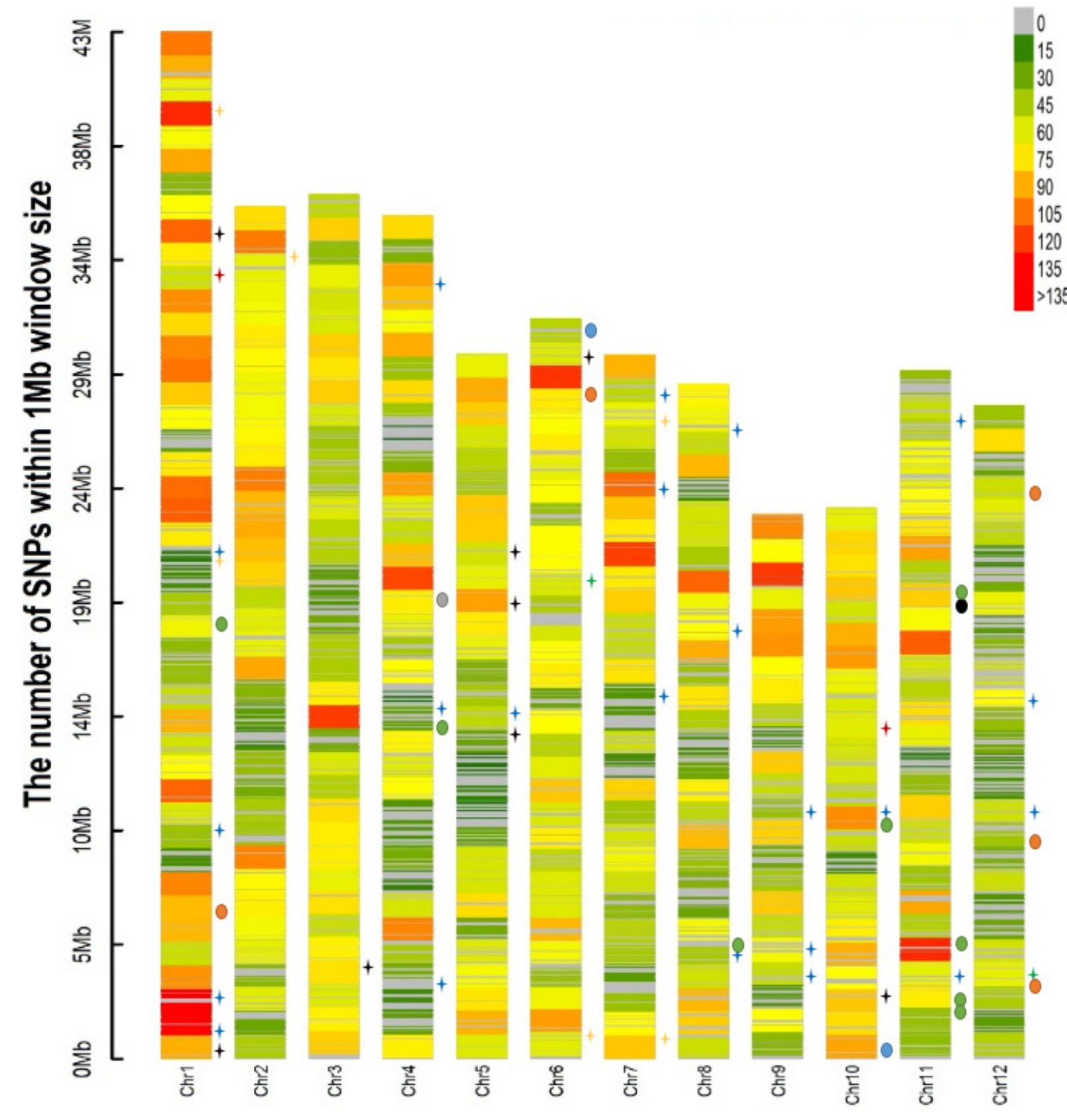

Figure 6. Single nucleotide polymorphism (SNP)-density plot and QTL positions for agronomic traits, nutrition, and bacterial leaf blight (BLB) resistance. +: Antc; +: BLB; +: DH; +: Fe; + GW; $\bullet$ : NP; ๑: PL; : RR; ๑: Zn; and ๑: GL.

\subsection{QTLs for Agronomic and Nutritional Traits}

1. DH: Eight QTLs were identified for days to heading on chromosomes 1, 3, 5, 6, and 10. Most of them were located on chromosome 5 (Table 3). The PVE of these QTLs varied from $9.3 \%$ to $14.7 \%$. $q D H_{1.1}, q D H_{1.3}, q D H_{5.2}, q D H_{6.1}$, and $q D H_{10.1}$ had PVE of more than $10 \%$ each. $q D H_{5.2}$ had the highest PVE (14.7\%).

2. GL: Only one QTL $\left(q G L_{4.1}\right)$ was identified for grain length on chromosome 4. The PVE of this QTL was $14 \%$.

3. GW: Two QTLs were identified for grain width, one each on chromosomes 2 and 4. $q G W_{2.1}$ and $q G W_{6.1}$ had a PVE of $12.6 \%$ and $14.4 \%$, respectively; both were identified at a very high $p$-value.

4. NP: Only one QTL $\left(q N P_{1.1}\right)$ was identified on chromosome 11 , with a PVE of $16.7 \%$.

5. PL: For panicle length, two QTLs were identified on chromosomes $6\left(q P L_{6.1}\right)$ and $10\left(q P L_{10.1}\right)$, with a PVE of $12.9 \%$ and $12.6 \%$, respectively. 
6. RR: In all, eight QTLs were identified for ripening ratio on chromosomes 1, 4, 8, 10, and 11 . Most of them were located on chromosome 11. The PVE of these QTLs varied from $12.0 \%$ to $17.5 \%$. The QTL $q R R_{11.4}$ had the highest PVE (17.5\%).

7. TGW: Four QTLs were identified for grain weight, two each on chromosomes 1 and 7. Three ( $q T G W 1.1, q T G W_{1.2}$, and $q T G W_{7.1}$ ) of them had a PVE of more than $10 \%$.

8. Fe: Two QTLs were identified for grain Fe content, one each on chromosomes 6 and 12. Both had a PVE of more than $10 \%$.

9. Zn: Five QTLs were identified for grain Zn content on chromosomes 1, 6, and 12, with three of them on chromosome 12. All of them had a PVE of more than $10 \% ; q Z n_{12.2}$ had the highest PVE (17.9\%).

10. AC: Two QTLs were identified for anthocyanin content, one each on chromosomes 1 and 10, with a PVE of $14.5 \%$ and $13.1 \%$, respectively.

\subsection{QTLs for BLB Resistance}

A total of 22 QTLs were mapped only for 11 of the 14 different Xoo strains screened on the colored rice panel. All of the QTLs had a PVE of more than $10 \%$, except $q B L B_{1.2}, q B L B_{1.4}$, and $q B L B_{4.3}$ (Table 4 and Figure 6). Four QTLs ( $q B L B_{4.3}, q B L B_{5.1}, q B L B_{7.2}$, and $\left.q B L B_{7.3}\right)$ were identified for resistance to Xoo strain PXO363. Three QTLs each were identified for resistance to Xoo strains PXO61 and PXO99.

\subsection{Candidate Genes Co-Located with the QTLS}

Most of the QTLs detected were co-located with either known QTLs or genes for the respective traits; also, some new QTLs were identified (Table 3). The PVE of the QTLs varied from 9.3\% to $17.9 \%$ (Table 3). The Antc QTL $q A n t c_{1.1}$ was co-located with the glu4 gene. The DH QTLs were co-located with PME1, lsi2, siz1, OsLti6b, dth1.1, OsCrRLK1L2, and OsFD2. qGL4.1 co-located with GIF1. Similarly, grain weight QTLs $q G W_{1.2}, q G W_{6.1}$, and $q G W_{7.1}$ were co-located with OsaLeg1, SSG6, qgw1.1, qgrl1-1, $A Q E D 046$, and SDGP7 (Table 3). For Fe and Zn, three of the seven QTLs were co-located with the metal homeostasis genes (Table 3). For BLB resistance, eight of the 22 QTLs ( $q B B_{1.4}, q B L B_{4.3}, q B L B_{5.1}$, $q B L B_{7.1}, q B L B_{7.3}, q B L B_{8.1}, q B L B_{8.3}$, and $\left.q B L B_{11.2}\right)$ were co-located with 12 known BLB genes or with their functionally-related genes (OsLOL2, Xa1, OsWRKY45, xa5, xa8, oscbt, rtGA2.1, OsGLP8, Os8N3, $x a 13, X a 3$, and Xa26) (Table 4). The PVE of the QTLs varied from 9.9\% to $12.9 \%$ (Table 4).

\subsection{Identification of Donor Lines for Grain Zn and Anthocyanin}

Among the colored rice samples, six high-Zn lines and another six high-AC lines were identified and are presented in Table 5. Among the selected lines, Zn content ranged from 24.8 to $26.6 \mathrm{mg} / \mathrm{kg}$, whereas AC was more than $295.6 \mathrm{mg} / \mathrm{Kg}$. However, only one accession, namely, Sayllebon, contained higher content of both $\mathrm{Zn}(24.8 \mathrm{mg} / \mathrm{kg})$ and $\mathrm{AC}(375.4 \mathrm{mg} / \mathrm{kg})$.

Table 5. Colored rice accessions with high grain $\mathrm{Zn}$ and anthocyanin.

\begin{tabular}{cccc}
\hline Germplasm & Zn (mg/kg) & Germplasm & AC (mg/kg) \\
\hline CR0021 & 26.6 & Sayllebon & 375.4 \\
Pantia & 25.6 & Filiwa & 368.3 \\
Quakor & 25.1 & Koni & 361.6 \\
Trunia & 25.0 & Fosagbe & 303.3 \\
Partio & 24.9 & Khao & 296.4 \\
Sayllebon & 24.8 & Ketan Kuwule & 295.6 \\
\hline
\end{tabular}

\section{Discussion}

Colored rice is a rich source of vitamins and minerals, containing several-fold higher nutrients than regularly consumed white rice, so it can contribute significantly to human health and nutrition [94-96]. 
Thus, efforts are being made to conserve, characterize, and cultivate colored rice accessions and promote the consumption of colored rice and brown rice as part of the major health and nutrition initiatives in many countries of Asia [24,97]. In the present study, we characterized colored rice accessions for nutritional, agronomic, and BLB resistance traits, and carried out association mapping and candidate gene analysis to facilitate the development of healthier rice varieties.

Biofortification has been proven to be one of the most cost-effective methods in combating $\mathrm{Fe}$ and $\mathrm{Zn}$ deficiencies [40,98-102]. However, the accumulation of mineral elements in the edible parts is a complex process involving multiple QTLs/genes and is highly influenced by environmental factors $[33,103]$. Biofortified rice varieties, with high grain mineral concentration, should be high yielding, with desirable grain quality traits, and resistant to major pests and diseases for their successful adoption $[16,104]$. Thus, an understanding of the molecular basis of all of these complex traits will help in precisely pyramiding several genes and QTLs to develop superior and farmer-adoptive nutritious rice varieties.

Mostly normal frequency distribution was observed for all the nutritional and agronomic traits, and skewed distribution for BLB resistance, indicating their polygenic and oligogenic/monogenic genetic control, respectively, which is the normal trend reported for these traits [105-108]. Some of the accessions with higher content of Zn and AC were CR0021, Quakor and Trunia and Sayllebon, Filiwa and Koni, respectively. They are useful for breeding as well as to directly promote them as healthier rice. Selection of rice donor parents with multiple beneficial traits seems to be a good strategy to reduce the impact of linkage drag in breeding. Our study found that red rice genotype, Sayllebon, which is high in both $\mathrm{Zn}$ and $\mathrm{AC}$, could be a valuable material for a breeding program for nutritious rice. Sayllebon/3-203 was also found to contain a higher amount of antioxidant compound $\gamma$-oryzanol (9.1 mg/100 g hulled rice) [109]. Even though higher Fe, Zn, and AC were reported in colored rice, our results showed that there was not much variation for $\mathrm{Fe}$, but wide ranges were observed for $\mathrm{Zn}(9.2$ to $26.6 \mathrm{mg} / \mathrm{Kg})$ and $\mathrm{AC}[2,35,107,110-112]$. A wide range of variability for different traits indicated the role of genotype as well as environmental effects on the expression of these traits. In general, rice accessions have less variability for Fe in the endosperm. Some of the colored rice genotypes may have high Fe in the endosperm; such accessions may be very rare. In contrast, the huge variability available for grain $\mathrm{Zn}$, anthocyanin content, and antioxidant compounds in colored rice can be exploited in breeding programs.

The correlations among nutritional and agronomic traits exhibited known trends. DH was negatively correlated with yield components, such as NP, RR, and TGW, and positively correlated with NSP; TGW was negatively associated with AC but, interestingly, it did not show any significant relationship with Fe and $\mathrm{Zn}$; AC was negatively correlated with most of the yield components and significantly positively correlated only with PL. Similarly, Fe and Zn were negatively correlated with $\mathrm{DH}$, whereas Fe and $\mathrm{Zn}$ had a highly significant positive correlation. Number of spikelets per panicle (NSP) is an important trait to determine the number of grains per unit area. Large variation in NSP was reported in previous studies [113-115]. According to Kato (1986) [116], RR is usually low in rice genotypes with a higher number of grains, which is in agreement with our results. Further, the significant positive correlation identified between $\mathrm{Fe}$ and $\mathrm{Zn}$ was supported by earlier findings $[117,118]$. Fe and $\mathrm{Zn}$ share the same genomic region or genes or biochemical pathways $[119,120]$. Even though QTLs/genes for highly correlated traits are co-located, they may be tightly linked or pleiotropic, but linkage drag must be eliminated through pre-breeding or precise introgression of the target region in elite genetic backgrounds [121].

The SNP density used in the analysis was very high, with an average density of one SNP for every $19.4 \mathrm{~kb}$. All the chromosomal regions were well covered without any significant gaps. A high-density SNP is desired for accurate QTL/gene detection [122,123]. In our population, limited subgroups and a higher number of marker pairs in complete LD were detected. The structure and PC analyses clearly grouped the accessions into two subgroups without admixtures, indicating free flow of genes within groups and less gene pool sharing across groups. We detected $74.3 \%$ of the marker pairs in 
complete LD, with an average LD distance of $1000 \mathrm{~kb}$, and, interestingly, one-third (36\%) of the LD pairs were less than $5 \mathrm{~Kb}$, indicating a high rate of recombination in the panel. The identification of subgroups and generating kinship data for use in association analysis are important to avoid spurious associations $[124,125]$. The low average LD distance with high recombination is essential for any association analyses to accurately detect the precise location of QTLs/genes [122]. We used structure with kinship $(\mathrm{Q}+\mathrm{K})$ information for GWAS analyses.

Genome-wide association study is widely used for genetic analyses to exploit genetic diversity in rice and to identify novel alleles for multiple traits [119,126-130]. In our study, GWAS detected multiple major loci for all the traits except for NSP and TGW. In total, 35 QTLs were identified for nutritional and agronomic traits at $p<0.0001$ (Table 4). They were distributed on all the chromosomes, except on chromosome 7, and the PVE of these QTLs varied from $9 \%$ to $18 \%$. The highest numbers of QTLs were identified for DH and RR. It is also interesting to note that $18(51 \%)$ QTLs for agronomic and micronutrient traits were co-located with either known QTLs or genes for the respective traits. Previous studies reported several QTLs and genes for agronomic, yield, and nutritional traits in various biparental and natural mapping populations in rice [119,131-137]. For BLB resistance, 22 QTLs were identified; $12(54 \%)$ of them were co-located with known BLB genes or with their functionally-related genes. The PVE of the QTLs varied from $9.9 \%$ to $12.9 \%$ (Table 4). The co-locations of candidate genes with QTLs provide the evidence for accuracy in mapping of genetic loci. With the recent advancements in rice genomics, there has been increasing accumulation of information on QTLs and genes for various traits in rice using different approaches $[138,139]$. Some of the genes for disease resistance, nutritional and grain quality, and agronomic traits have been cloned, functionally validated, and successfully used in breeding programs $[139,140]$. However, there is a need to continuously search for novel alleles to cater to the diverse needs of breeding programs to mitigate the adverse effects of climate change and to meet the food and nutritional demands of farmers and consumers [38].

Prioritization of the candidate genes underlying major-effect QTLs for complex traits, and their functional validation, is necessary to understand their influence on phenotype and also to develop functional markers for use in breeding [141-144]. Several QTLs identified in this study were co-located with known or functionally-related genes. $q A n t c_{1.1}$ was co-located with the glu4 gene, which is related to seed glutelin quality (eating quality). The DH QTLs were co-located with PME1, lsi2, siz1, OsLti6b, dth1.1, OsCrRLK1L2^, and OsFD2. PME1, siz1', and OsFD2 genes are known to be involved in anther and leaf development [53,55,57]. $q G L_{4.1}$ co-located with GIF1, the gene that regulates grain size and grain filing in rice [59]. Similarly, grain weight QTLs $q G W_{1.2}, q G W_{6.1}$, and $q G W_{7.1}$ were co-located with OsaLeg1, SSG6, qgw1.1, qgrl1-1, AQED046, and SDGP7. SSG6 is a substandard starch granule-6 gene that is involved in the development of large starch granules in the endosperm [61], whereas AQED46 is related to 1000-grain weight [62]. The results of this study suggest that SSG6 is a novel protein that controls grain size. SSG6 will be a useful molecular tool for future starch breeding and applications. For Fe and $\mathrm{Zn}$, three of the seven QTLs were co-located with the metal homeostasis genes. These were zinc ion transporter, OsCNGC16, OsDof, OsHMA9, OsNRAMP3, OsbZip85, OsNRAMP7, and ZFP252.

Among the BLB resistance QTLs, eight of the 22 QTLs $\left(q B L B_{1.4}, q B L B_{4.3}, q B L B_{5.1}, q B L B_{7.1}\right.$, $q B L B_{7.3}, q B L B_{8.1}, q B L B_{8.3}$, and $q B L B_{11.2}$ ) were co-located with 12 known BLB genes or with their functionally-related genes (OsLOL2, Xa1, OsWRKY45, xa5, xa8, oscbt, rtGA2.1, OsGLP8, Os8N3, xa13, $\mathrm{X} a 3$, and $\mathrm{X} a 26)$, respectively. Furthermore, the BLB resistance gene-rich region of chromosome 8 was identified with two QTLs ( $q B L B_{8.1}$ and $q B L B_{8.3}$ ) in which OsGLP8, Os8N3, and $x a 13$ were found to be co-located. $q B L B_{11.2}$ also co-located with two important BLB genes, $X a 3$ and $X a 26$. This $q B L B_{11.2}$ was also identified by other studies [145-149]. GWAS also identified SNP markers near known genes that are related to disease resistance and stress tolerance such as OsRLCK19, OsLOL2, and OsGLP8, which are plausible candidate resistance genes on chromosomes 1 and 8. Similarly, a GWAS in a ulti-Parent Advanced Generation Inter-Cross (MAGIC) population identified several major and minor loci for BLB resistance [150]. Although major BLB resistance genes have been successfully introgressed using marker-assisted breeding, widespread use of these varieties narrows the genetic base, resulting in 
high selection pressure against the prevailing BLB strains, resulting in more virulent strains that could overcome the major $\mathrm{R}$ genes of rice. Thus, pyramiding of small-effect BLB QTLs along major genes is necessary for a more sustainable BLB resistance $[106,151]$. This $q B L B_{11.2}$ region was also very close to the location of four reported blast resistance genes, namely, Pik1, Pik2, Pikm, and Pik- $p$ [152-154]; thus, $q B L B_{11.2}$ might be useful for the development of BLB and blast disease resistance in rice.

\section{Conclusions}

This study reports QTLs identified for nutritional, agronomic, and BLB resistance traits using GWAS in a colored rice diversity panel. Colored rice accessions have higher nutritive value than non-pigmented rice genotypes as they contain higher levels of micronutrients and antioxidant compounds. The lines with higher nutritional value identified in this study could be used as donor parents for nutritional traits, and crossed with high-yielding mega-varieties to develop new high-yielding and nutritious rice cultivars. Furthermore, the identified BLB resistance loci might be beneficial in developing rice cultivars resistant to BLB. The introgression of major-effect QTLs for the desired traits identified in this study will also enhance the efficiency of marker-assisted breeding programs.

Supplementary Materials: The following will be available online at http:/ / www.mdpi.com/2073-4425/10/1/ 30/s1, Table S1: List of accessions used in the GWAS analysis.

Author Contributions: Conceptualization, funding acquisition, supervision and editing, R.R., C.M.V.C., B.P.M.S., and J.H.C.; methodology and experiment, I.P.N., C.C., M.A.I.-A., R.J.D.L., and G.I.D.-E.; data analysis and writing, G.I.D.-E., A.A., A.A.S.N., A.M.I., V.M.J., and M.S.D.

Funding: The authors would like to thank HarvestPlus for funding the rice zinc biofortification. This work was also supported by a grant from the Next-Generation BioGreen 21 Program (Plant Molecular Breeding Center, No. PJ01319603), Rural Development Administration, Republic of Korea, and a Research University Grant (DCP-2017-004-2) from Universiti Kebangsaan Malaysia.

Conflicts of Interest: The authors declare no conflict of interest.

\section{References}

1. Awika, J.M. Advances in Cereal Science: Implications to Food Processing and Health Promotion; ACS Symposium Series; American Chemical Society: Washington, DC, USA, 2011.

2. Kushwaha, U.K.S. Black Rice: Research, History and Development; Springer: Basel, Switzerland, 2016.

3. Surendiran, G.; Alsaif, M.; Kapourchali, F.R.; Moghadasian, M. Nutritional constituents and health benefits of wild rice (Zizania spp.). Nutr. Rev. 2014, 72, 227-236. [CrossRef] [PubMed]

4. Ahmad, F.; Hanafi, M.M.; Hakim, M.A.; Rafii, M.Y.; Arolu, I.W.; Akmar Abdullah, S.N. Genetic Divergence and Heritability of 42 Coloured Upland Rice Genotypes (Oryza sativa) as Revealed by Microsatellite Markers and Agro-Morphological Traits. PLoS ONE 2015, 10, e0138246. [CrossRef] [PubMed]

5. Melini, V.; Acquistucci, R. Health-Promoting Compounds in Pigmented Thai and Wild Rice. Foods 2017, 6, 9. [CrossRef] [PubMed]

6. Issara, U.; Rawdkuen, S. Rice bran: A potential of main ingredient in healthy beverage. Int. Food Res. J. 2017, 23, 2306-2318.

7. Goufo, P.; Trindade, H. Rice antioxidants: Phenolic acids; flavonoids; anthocyanins; proanthocyanidins; tocopherols; tocotrienols; $\gamma$-oryzanol; and phytic acid. Food Sci. Nutr. 2014, 2, 75-104. [CrossRef] [PubMed]

8. Chaudhari, P.R.; Tamrakar, N.T.; Singh, L.; Tandon, A.; Sharma, D. Rice nutritional and medicinal properties: A review article. J. Pharmacogn. Phytochem. 2018, 7, 150-156.

9. Hu, C.; Zawistowski, J.; Ling, W.; Kitt, D.D. Black Rice (Oryza sativa L. indica) Pigmented fraction suppresses both reactive oxygen species and nitric oxide in chemical and biological model systems. J. Agric. Food Chem. 2003, 51, 5271-5277.

10. Oki, T.; Masuda, M.; Kobayashi, M.; Nishiba, Y.; Furuta, S.; Suda, I.; Sato, T. Polymeric procyanidins as radical-scavenging components in red-hulled rice. J. Agric. Food Chem. 2002, 50, 7524-7529. [CrossRef]

11. Khush, G.S.; Lee, S.; Cho, J.I.; Jeon, J.S. Biofortification of crops for reducing malnutrition. Plant Biotechnol. Rep. 2012, 6, 195-202. [CrossRef] 
12. Mao, H.; Wang, J.; Wang, Z.; Zan, Y.; Lyons, G.; Zou, C. Using agronomic biofortification to boost zinc; selenium; and iodine concentrations of food crops grown on the loess plateau in China. J. Soil Sci. Plant Nutr. 2014, 14, 459-470. [CrossRef]

13. Impa, S.M.; Johnson-Beebout, S.E. Mitigating zinc deficiency and achieving high grain $\mathrm{Zn}$ in rice through integration of soil chemistry and plant physiology research. Plant Soil 2012, 361, 3-41. [CrossRef]

14. Institute of Medicine Food and Nutrition Board (IMFNB). Dietary Reference Intakes for Vitamin A, Vitamin K, Arsenic, Boron, Chromium, Copper, Iodine, Iron, Manganese, Molybdenum, Nickel, Silicon, Vanadium and Zinc; National Academy Press: Washington, DC, USA, 2001.

15. Wang, L.C.; Busbey, S. Images in clinical medicine acquired Acrodermatitis enteropathica. N. Engl. J. Med. 2005, 352, 1121. [CrossRef] [PubMed]

16. Bouis, H.E. Micronutrient fortification of plants through plant breeding: Can it improve nutrition in man at low cost? Proc. Nutr. Soc. 2007, 62, 403-411. [CrossRef]

17. Cheng, Z.-Q.; Huang, X.-Q.; Zhang, Y.-Z.; Qian, J.; Yang, M.-Z.; Wu, C.-J.; Liu, J.-F. Diversity in the Content of Some Nutritional Components in Husked Seeds of Three Wild Rice Species and Rice Varieties in Yunnan Province of China. J. Integr. Plant Biol. 2005, 47, 1260-1270. [CrossRef]

18. Singh, S.P.; Gruissem, W.; Bhullar, N.K. Single genetic locus improvement of iron, zinc and $\beta$-carotene content in rice grains. Sci. Rep. 2017, 7, 6883. [CrossRef] [PubMed]

19. Galli, F.; Piroddi, M.; Annetti, C.; Aisa, C.; Floridi, E.; Floridi, A. Oxidative stress and reactive oxygen species. Contrib. Nephrol. 2005, 149, 240-260. [PubMed]

20. Sharma, S.; Chunduri, V.; Kumar, A.; Kumar, R.; Khare, P.; Kondepudi, K.K.; Bishnoi, M.; Garg, M. Anthocyanin bio-fortified colored wheat: Nutritional and functional characterization. PLOS ONE 2018, 13, e0194367. [CrossRef] [PubMed]

21. Garg, M.; Sharma, N.; Sharma, S.; Kapoor, P.; Kumar, A.; Chunduri, V.; Arora, P. Biofortified crops generated by breeding; agronomy; and transgenic approaches are improving lives of millions of people around the world. Front. Nutr. 2018, 5, 12. [CrossRef]

22. Rahman, S.; Sharma, M.P.; Sahai, S. Nutritional and medicinal values of some indigenous rice varieties. Indian J. Tradit. Knowl. 2006, 5, 454-458.

23. Rana, J.C.; Negi, K.S.; Wani, S.A.; Saxena, S.; Pradheep, K.; Kak, A.; Pareek, S.K.; Sofi, P.A. Genetic resources of rice in the Western Himalayan region of India: Current status. Genet. Resour. Crop Evol. 2009, 56, 963-973. [CrossRef]

24. Ahuja, U.; Ahuja, S.C.; Chaudhary, N.; Thankrar, R. Red Rices-Past, Present, and Future. Asian Agric.-Hist. 2007, 11, 291-304.

25. Fasahat, P.; Abdullah, A.; Muhammad, K.; Karupaiah, T.; Ratnam, W. Red pericarp advanced breeding lines derived from Oryza rufipogon $\times$ Oryza sativa: Physicochemical properties, total antioxidant activity, phenolic compounds and Vitamin E content. Adv. J. Food Sci. Technol. 2012, 4, 155-165.

26. Kinoshita, N.; Kato, M.; Koyasaki, K.; Kawashima, T.; Nishimura, T.; Hirayama, Y.; Takamure, I.; Sato, T.; Kato, K. Identification of quantitative trait loci for rice grain quality and yield-related traits in two closely related Oryza sativa L. subsp. japonica cultivars grown near the northernmost limit for rice paddy cultivation. Breed. Sci. 2017, 67, 191-206. [CrossRef] [PubMed]

27. Lou, J.; Chen, L.; Yue, G.; Lou, Q.; Mei, H.; Xiong, L.; Luo, L. QTL mapping of grain quality traits in rice. J. Cereal Sci. 2009, 50, 145-151. [CrossRef]

28. Ngu, M.S.; Thomson, M.J.; Bhuiyan, M.A.; Ho, C.; Wickneswari, R. Fine mapping of a grain weight quantitative trait locus, $q G W 6$, using near isogenic lines derived from Oryza rufipogon IRGC105491 and Oryza sativa cultivar MR219. Genet. Mol. Res. 2014, 13, 9477-9488. [CrossRef] [PubMed]

29. Yadav, S.; Anuradha, G.; Kumar, R.R.; Vemireddy, L.R.; Sudhakar, R.; Donempudi, K.; Venkata, D.; Jabeen, F.; Narasimhan, Y.K.; Marathi, B.; et al. Identification of QTLs and possible candidate genes conferring sheath blight resistance in rice (Oryza sativa L.). SpringerPlus 2015, 4, 175. [CrossRef] [PubMed]

30. Gowda, S.J.M.; Randhawa, G.J.; Bisht, I.S.; Firke, P.K.; Singh, A.K.; Abraham, Z.; Dhillon, B.S. Morpho-agronomic and simple sequence repeat-based diversity in colored rice (Oryza sativa L.) germplasm from peninsular India. Genet. Resour. Crop Evol. 2011, 59, 179-189. [CrossRef]

31. Ji, H.C.; Kim, Y.I.; Lee, H.B.; Cho, J.; Seo, S.; Yamakawa, T. Genetic diversity of coloured rice lines based on botanical characteristics and simple sequence repeats (SSR) markers. J. Fac. Agric. Kyushu Univ. 2007, 52, 287-293. 
32. Pathak, K.; Rahman, S.W.; Bhagawati, S.; Bhabesh, G.B. Assessment of nutritive and antioxidant properties of some indigenous pigmented hill rice (Oryza sativa L.) cultivars of Assam. Indian J. Agric. Res. 2017, 51, 214-220. [CrossRef]

33. Swamy, B.P.M.; Descalsota, G.I.L.; Nha, C.T.; Amparado, A.; Inabangan-Asilo, M.A.; Manito, C. Identification of genomic regions associated with agronomic and biofortification traits in $\mathrm{DH}$ populations of rice. PLOS ONE 2018, 13, e0201756. [CrossRef]

34. Pengkumsri, N.; Chaiyasut, C.; Saenjum, C.; Sirilun, S.; Peerajan, S.; Suwannalert, P.; Sirisattha, S.; Sivamaruthi, B.S. Physicochemical and antioxidative properties of black, brown and red rice varieties of northern Thailand. Food Sci. Technol. 2015, 35, 331-338. [CrossRef]

35. Meng, F.; Wei, Y.; Yang, X. Iron content and bioavailability in rice. J. Trace Elem. Med. Biol. 2005, 18, 333-338. [CrossRef] [PubMed]

36. Wang, C.X.; Shu, Q.Y. Fine mapping and candidate gene analysis of purple pericarp gene $\mathrm{Pb}$ in rice (Oryza sativa L.). Chin. Sci. Bull. 2007, 52, 3097-3104. [CrossRef]

37. Shao, Y.; Jin, L.; Zhang, G.; Lu, Y.; Shen, Y.; Bao, J. Association mapping of grain color, phenolic content, flavonoid content and antioxidant capacity in dehulled rice. Theor. Appl. Genet. 2011, 122, 1005-1016. [CrossRef] [PubMed]

38. Huang, X.; Wei, X.; Sang, T.; Zhao, Q.; Feng, Q.; Zhao, Y. Genome-wide association studies of 14 agronomic traits in rice landraces. Nat. Genet. 2010, 42, 961-967. [CrossRef] [PubMed]

39. Xu, T.Y.; Sun, J.; Chang, H.L.; Zheng, H.L.; Wang, J.G.; Liu, H.L.; Yang, L.M.; Zhao, H.W.; Zou, D.T. QTL mapping for anthocyanin and proanthocyanidin content in red rice. Euphytica 2017, 213, 243. [CrossRef]

40. Swamy, B.P.M.; Rahman, M.A.; Inabangan-Asilo, M.A. Advances in breeding for high grain zinc in rice. Rice 2016, 9, 49. [CrossRef]

41. Swamy, B.P.M.; Shamsudin, N.A.A.; Rahman, S.N.A.; Mauleon, R.; Ratnam, W.; Cruz, M.T.S.; Kumar, A. Association mapping of yield and yield-related traits under reproductive stage drought stress in rice (Oryza sativa L.). Rice 2017, 10, 21. [CrossRef]

42. IRRI. Standard Evaluation System for Rice (SES); International Rice Research Institute (IRRI): Los Baños, Philippines, 2002.

43. Abdel-Aal, E.-S.M.; Young, J.C.; Rabalski, I. Anthocyanin composition in black, blue, pink, purple, and red cereal grains. J. Agric. Food Chem. 2006, 54, 4696-4704. [CrossRef]

44. Elshire, R.J.; Glaubitz, J.C.; Sun, Q.; Poland, J.A.; Kawamoto, K.; Buckler, E.S.; Mitchell, S.E. A Robust, Simple Genotyping-by-Sequencing (GBS) Approach for High Diversity Species. PLoS ONE 2011, 6, e19379. [CrossRef]

45. Glaubitz, J.C.; Casstevens, T.M.; Fei, L.; Harriman, J.; Elshire, R.J.; Qi, S.; Buckler, E.S. TASSEL-GBS: A High Capacity Genotyping by Sequencing Analysis Pipeline. PLoS ONE 2014, 9, e90346. [CrossRef] [PubMed]

46. Bradbury, P.J.; Zhang, Z.; Kroon, D.E.; Casstevens, T.M.; Ramdoss, Y.; Buckler, E.S. TASSEL: Software for association mapping of complex traits in diverse samples. Bioinformatics 2007, 23, 2633-2635. [CrossRef] [PubMed]

47. Wickham, H. Ggplot2: Elegant Graphics for Data Analysis; Springer: New York, NY, USA, 2008.

48. Evanno, G.; Regnaut, S.; Goudet, J. Detecting the number of clusters of individuals using the software STRUCTURE: A simulation study. Mol. Ecol. 2005, 14, 2611-2620. [CrossRef] [PubMed]

49. Earl, D.A.; Von Holdt, B.M. STRUCTURE HARVESTER: A website and program for visualizing STRUCTURE output and implementing the Evanno method. Conserv. Genet. Resour. 2012, 4, 359-361. [CrossRef]

50. Murdifin, M.; Pakki, E.; Rahim, A.; Syaiful, S.A.; Ismail, Y.M.; Bahar, M.A. Physicochemical Properties of Indonesian Pigmented Rice (Oryza sativa Linn.) Varieties from South Sulawesi. Asian J. Plant Sci. 2015, 14, 59-65. [CrossRef]

51. Qu, L.Q.; Wei, X.L.; Satoh, H.; Kumamaru, T.; Ogawa, M.; Takaiwa, F. Biochemical and molecular characterization of a rice glutelin allele for the GluA-1 gene. Theor. Appl. Genet. 2003, 10, 20-25. [CrossRef] [PubMed]

52. SHIGEN. Available online: https://shigen.nig.ac.jp/rice/oryzabase/gene/advanced/list (accessed on 2 November 2018).

53. Kang, K.; Park, S.; Natsagdorj, U.; Kim, Y.S.; Back, K. Methanol is an endogenous elicitor molecule for the synthesis of tryptophan and tryptophan-derived secondary metabolites upon senescence of detached rice leaves. Plant J. 2011, 66, 247-257. [CrossRef] [PubMed] 
54. Ma, J.F.; Yamaji, N.; Mitani, N.; Tamai, K.; Konoshi, S.; Fujiwara, T.; Katsuhara, M.; Yano, M. An efflux transporter of silicon in rice. Nature 2007, 448, 209-212. [CrossRef] [PubMed]

55. Thangasamy, S.; Guo, C.L.; Chuang, M.H.; Lai, M.H.; Chen, J.; Jauh, G.Y. Rice SIZ1, a SUMO E3 ligase, controls spikelet fertility through regulation of anther dehiscence. New Phytol. 2011, 189, 869-882. [CrossRef]

56. Kim, S.H.; Kim, J.Y.; Kim, S.J.; An, K.S.; An, G.; Kim, S.R. Isolation of cold stress-responsive genes in the reproductive organs, and characterization of the OsLti6b gene from rice (Oryza sativa L.). Plant Cell Rep. 2007, 26, 1097-1110. [CrossRef]

57. Tsuji, H.; Nakamura, H.; Taoka, K.I.; Shimamoto, K. Functional Diversification of FD Transcription Factors in Rice, Components of Florigen Activation Complexes. Plant Cell Physiol. 2013, 54, 385-397. [CrossRef] [PubMed]

58. Du, J.; Zeng, D.; Wang, B.; Qian, Q.; Zheng, S.; Ling, H.Q. Environmental effects on mineral accumulation in rice grains and identification of ecological specific QTLs. Environ. Geochem. Health 2013, 35, 161-170. [CrossRef] [PubMed]

59. Wang, E.; Wang, J.; Zhu, X.; Hao, W.; Wang, L.; Li, Q.; Zhang, L.; He, W.; Lu, B.; Lin, H.; et al. Control of rice grain-filling and yield by a gene with a potential signature of domestication. Nat. Genet. 2008, 40, 1370-1374. [CrossRef]

60. Chrisoff, A.P.; Turchetto-Zolet, A.C.; Margis, R. Uncovering legumain genes in rice. Plant Sci. 2014, $215-216$. [CrossRef]

61. Matsushima, R.; Maekawa, M.; Kusano, M.; Tomita, K.; Kondo, H.; Nishimura, H.; Crofts, N.; Fujita, N.; Sakamoto, W. Amyloplast Membrane Protein SUBSTANDARD STARCH GRAIN6 Controls Starch Grain Size in Rice Endosperm. Plant Physiol. 2016, 170, 1445-1459. [CrossRef] [PubMed]

62. Rice Genomics, Genome India. Available online: http://www.genomeindia.org/biocuration/usr/ (accessed on 2 November 2018).

63. Takashi, O.; Perigio, B.F.; Takayuki, S.; Tatsuro, H.; Tomio, T.; Hikaru, S.; Yasunori, N. Expression profiling of genes involved in starch synthesis in sink and source organs of rice. J. Exp. Bot. 2005, 56, 3229-3244. [CrossRef]

64. Kiribuchi, K.; Sugimori, M.; Takeda, M.; Otani, T.; Okada, K.; Onodera, H.; Ugaki, M.; Tanaka, Y.; Tomiyama-Akimoto, C.; Yamaguchi, T.; et al. RERJ1, a jasmonic acid-responsive gene from rice, encodes a basic helix-loop-helix protein. Biochem. Biophys. Res. Commun. 2004, 325, 857-863. [CrossRef] [PubMed]

65. Xiang, Y.; Huang, Y.; Xiong, L. Characterization of Stress-Responsive CIPK Genes in Rice for Stress Tolerance Improvement. Plant Physiol. 2007, 144, 1416-1428. [CrossRef]

66. Nakagawa, M.; Shimamoto, K.; Kyozuka, J. Overexpression of RCN1 and RCN2, rice TERMINAL FLOWER 1/CENTRORADIALIS homologs, confers delay of phase transition and altered panicle morphology in rice. Plant J. 2002, 29, 743-750. [CrossRef]

67. Lee, S.; Kim, Y.Y.; Lee, Y.; An, G. Rice $\mathrm{P}_{1 \mathrm{~B}}$-Type Heavy-Metal ATPase, OsHMA9, Is a Metal Efflux Protein. Plant Physiol. 2007, 145, 831-842. [CrossRef]

68. Lieberherr, D.; Thao, N.P.; Nakashima, A.; Umemura, K.; Kawasaki, T.; Shimamoto, K. A sphingolipid elicitor-inducible mitogen-activated protein kinase is regulated by the small GTPase OsRac1 and heterotrimeric G-protein in rice. Plant Physiol. 2005, 138, 1644-1652. [CrossRef] [PubMed]

69. Narayanan, N.N.; Vasconcelos, M.W.; Grusak, M.A. Expression profiling of Oryza sativa metal homeostasis genes in different rice cultivars using a cDNA macroarray. Plant Physiol. Biochem. 2007, 45, 277-286. [CrossRef] [PubMed]

70. Nonomura, K.I.; Eiguchi, M.; Nakano, M.; Takashima, K.; Komeda, N.; Fukuchi, S.; Miyazaki, S.; Miyao, A.; Hirochika, H.; Kurata, N. A novel RNA-recognition-motif protein is required for premeiotic G1/S-phase transition in rice (Oryza sativa L.). PLoS Genet. 2011, 7, e1001265. [CrossRef] [PubMed]

71. Xu, D.Q.; Huang, J.; Guo, S.Q.; Yang, X.; Bao, Y.M.; Tang, H.J.; Zhang, H.S. Overexpression of a TFIIIA-type zinc finger protein gene ZFP252 enhances drought and salt tolerance in rice (Oryza sativa L.). FEBS Lett. 2008, 582, 1037-1043. [CrossRef]

72. Vij, S.; Giri, J.; Dansana, P.K.; Kapoor, S.; Tyagi, A.K. The Receptor-Like Cytoplasmic Kinase (OsRLCK) Gene Family in Rice: Organization, Phylogenetic Relationship, and Expression during Development and Stress. Mol. Plant 2008, 1, 732-750. [CrossRef] [PubMed]

73. $\mathrm{Xu}, \mathrm{C} . ; \mathrm{He}, \mathrm{C}$. The rice OsLOL2 gene encodes a zinc finger protein involved in rice growth and disease resistance. Mol. Genet. Genom. 2007, 278, 85-94. [CrossRef] 
74. Ishii, T.; Numaguchi, K.; Miura, K.; Yoshida, K.; Thanh, P.T.; Htun, T.M.; Yamasaki, M.; Komeda, N.; Matsumoto, T.; Terauchi, R.; et al. OsLG1 regulates a closed panicle trait in domesticated rice. Nat. Genet. 2013, 45, 462-465. [CrossRef]

75. Yoshimura, S.; Yamanouchi, U.; Katayose, Y.; Toki, S.; Wang, Z.X.; Kono, I.; Kurata, N.; Yano, M.; Iwata, N.; Sasaki, T. Expression of Xa1, a bacterial blight-resistance gene in rice, is induced by bacterial inoculation. Proc. Natl. Acad. Sci. USA 1998, 95, 1663-1668. [CrossRef]

76. Tao, Z.; Liu, H.; Qiu, D.; Zhou, Y.; Li, X.; Xu, C.; Wang, S. A Pair of Allelic WRKY Genes Play Opposite Roles in Rice-Bacteria Interactions. Plant Physiol. 2009, 151, 936-948.

77. Iyer, A.S.; McCouch, S.R. The rice bacterial blight resistance gene xa5 encodes a novel form of disease resistance. Mol. Plant-Microbe Interact. 2004, 17, 1348-1354. [CrossRef]

78. Shimono, M.; Koga, H.; Akagi, A.Y.A.; Hayashi, N.; Goto, S.; Sawada, M.; Kurihara, T.; Matsushita, A.; Sugano, S.; Jiang, C.-J.; et al. Rice WRKY45 plays important roles in fungal and bacterial disease resistance. Mol. Plant Pathol. 2011, 13, 83-94. [CrossRef] [PubMed]

79. Shimono, M.; Sugano, S.; Nakayama, A.; Jiang, C.-J.; Ono, K.; Toki, S.; Takatsuji, H. Rice WRKY45 Plays a Crucial Role in Benzothiadiazole-Inducible Blast Resistance. Plant Cell 2007, 19, 2064-2076. [CrossRef] [PubMed]

80. Akagi, A.; Fukushima, S.; Okada, K.; Jiang, C.-J.; Yoshida, R.; Nakayama, A.; Shimono, M.; Sugano, S.; Yamane, H.; Takatsuji, H. WRKY45-dependent priming of diterpenoid phytoalexin biosynthesis in rice and the role of cytokinin in triggering the reaction. Plant Mol. Biol. 2014, 86, 171-183. [CrossRef] [PubMed]

81. Zhou, J.; Jiao, F.F.; Wu, Z.; Li, Y.; Wang, X.; He, X.; Zhong, W.; Wu, P. OsPHR2 Is Involved in Phosphate-Starvation Signaling and Excessive Phosphate Accumulation in Shoots of Plants. Plant Physiol. 2008, 146, 1673-1686. [CrossRef] [PubMed]

82. Tsukiyama, T.; Teramoto, S.; Yasuda, K.; Horibata, A.; Mori, N.; Okumoto, Y.; Teraishi, M.; Saito, H.; Onishi, A.; Tamura, K.; et al. Loss-of-function of a ubiquitin-related modifier promotes the mobilization of the active MITE mPing. Mol. Plant 2013, 6, 790-801. [CrossRef]

83. Koo, S.C.; Choi, M.S.; Chun, H.J.; Shin, D.B.; Park, B.S.; Kim, Y.H.; Park, H.M.; Seo, H.S.; Song, J.T.; Kang, K.Y.; et al. The Calmodulin-Binding Transcription Factor OsCBT Suppresses Defense Responses to Pathogens in Rice. Mol. Cells 2009, 563-570. [CrossRef]

84. Singh, K.; Vikal, Y.; Singh, S.; Leung, H.; Dhaliwal, H.S.; Khush, G.S. Mapping of bacterial blight resistance gene $\mathrm{x} a_{8}$ using microsatellite markers. Rice Genet. Newsl. 2002, 19, 94-96.

85. Komatsu, M.; Chujo, A.; Nagato, Y.; Shimamoto, K.; Kyozuka, J. FRIZZY PANICLE is required to prevent the formation of axillary meristems and to establish floral meristem identity in rice spikelets. Development 2003, 130, 3841-3850. [CrossRef]

86. Fitzgerald, H.A.; Canlas, P.E.; Chern, M.-S.; Ronald, P.C. Alteration of TGA factor activity in rice results in enhanced tolerance to Xanthomonas oryzae pv. oryzae. Plant J. 2005, 43, 335-347. [CrossRef]

87. Manosalva, P.M.; Davidson, R.M.; Liu, B.; Zhu, X.; Hulbert, S.H.; Leung, H.; Leach, J.E. A Germin-Like Protein Gene Family Functions as a Complex Quantitative Trait Locus Conferring Broad-Spectrum Disease Resistance in Rice. Plant Physiol. 2009, 149, 286-296. [CrossRef]

88. Chu, Z.; Yuan, M.; Yao, J.; Ge, X.; Yuan, B.; Xu, C.; Li, X.; Fu, B.; Li, Z.; Bennetzen, L.; et al. Promoter mutations of an essential gene for pollen development result in disease resistance in rice. Genes Dev. 2006, 1250-1255. [CrossRef] [PubMed]

89. Yang, B.; Sugio, A.; White, F.F. Os8N3 is a host disease-susceptibility gene for bacterial blight of rice. Proc. Natl. Acad. Sci. USA 2006, 103, 10503-10508. [CrossRef] [PubMed]

90. Chen, H.; Wang, S.; Zhang, Q. A new gene for bacterial blight resistance in rice located on chromosome 12 identified from Minghui 63, an elite restorer line. Phytopathology 2002, 92, 750-754. [CrossRef]

91. Suzuki, Y.; Ohkubo, M.; Hatakeyama, H.; Ohashi, K.; Yoshizawa, R.; Kojima, S.; Hayakawa, T.; Yamaya, T.; Mae, T.; Makino, A. Increased Rubisco content in transgenic rice transformed with the 'sense' rbcS gene. Plant Cell Physiol. 2007, 48, 626-637. [CrossRef] [PubMed]

92. Gamuyao, R.; Chin, J.H.; Pariasca-Tanaka, J.; Pesaresi, P.; Catausan, S.; Dalid, C.; Slamet-Loedin, I.; Tecson-Mendoza, E.M.; Wissuwa, M.; Heuer, S. The protein kinase Pstol1 from traditional rice confers tolerance of phosphorus deficiency. Nature 2012, 488, 535-539. [CrossRef] [PubMed]

93. Chen, X.; Shi, J.; Hao, X.; Liu, H.; Shi, J.; Wu, Y.; Wu, Z.; Chen, M.; Wu, P.; Mao, C. OsORC3 is required for lateral root development in rice. Plant J. 2013, 74, 339-350. [CrossRef] 
94. Goffman, F.D.; Bergman, C.J. Rice kernel phenolic content and its relationship with antiradical efficiency. J. Sci. Food Agric. 2004, 84, 1235-1240. [CrossRef]

95. Shen, Y.; Jin, L.; Xiao, P.; Lu, Y.; Bao, J.S. Total phenolics, flavonoids, antioxidant capacity in rice grain and their relations to grain color, size and weight. J. Cereal Sci. 2009, 49, 106-111. [CrossRef]

96. Gunaratne, A.; Wu, K.; Li, D.; Bentota, A.; Corke, H.; Cai, Y.Z. Antioxidant activity and nutritional quality of traditional red-grained rice varieties containing proanthocyanidins. Food Chem. 2013, 138, 1153-1161. [CrossRef]

97. Wuryandani, S.; Ismoyowati, D.; Nugrahini, AD. STP analysis in marketing pigmented rice as functional food. In Proceedings of the ICoA Conference, Matsuyama, Japan, 7-9 November 2015.

98. WHO. WHO Guidelines on Food Fortification with Micronutrients; World Health Organization: Geneva, Switzerland, 2006.

99. Lucca, P.; Hurrell, R.; Potrykus, I. Genetic engineering approaches to improve the bioavailability and the level of iron in rice grains. Theor. Appl. Genet. 2001, 102, 392-397. [CrossRef]

100. Welch, R.M.; Graham, R.D. Breeding crops for enhanced micronutrient content. Plant Soil 2002, 245, $205-214$. [CrossRef]

101. Bashir, K.; Ishimaru, Y.; Nishizawa, N.K. Iron uptake and loading into rice grains. Rice 2010, 3, 122-130. [CrossRef]

102. Goto, F.; Yoshihara, T.; Shigemoto, N.; Toki, S.; Takaiwa, F. Iron fortification of rice seed by the soybean ferritin gene. Nat. Biotechnol. 1999, 17, 282-286. [CrossRef] [PubMed]

103. Gregorio, G.B. Progress in breeding for trace minerals in staple crops. J. Nutr. 2002, 132, 500-502. [CrossRef] [PubMed]

104. Welch, R.M.; Graham, R.D. Breeding for micronutrients in staple food crops from a human nutrition perspective. J. Exp. Bot. 2004, 55, 353-364. [CrossRef] [PubMed]

105. McDowell, J.M.; Woffenden, B.J. Plant disease resistance genes: Recent insights and potential applications. Trends Biotechnol. 2003, 21, 178-183. [CrossRef]

106. Nagata, K. Ecophysiological traits and genetic analysis of yield and ripening in high-yielding semi-dwarf indica rice varieties. Jpn. Agric. Res. Q. 2006, 40, 307-316. [CrossRef]

107. Lu, K.; Li, L.Z.; Zheng, X.F.; Zhang, Z.H.; Mou, T.M.; Hu, Z.L. Quantitative trait loci controlling Cu, Ca, Zn, $\mathrm{Mn}$ and Fe content in rice grains. J. Genet. 2008, 87, 305-310. [CrossRef]

108. Xue, W.; Xing, Y.; Weng, X.; Zhao, Y.; Tang, W.; Wang, L.; Zhou, H.; Yu, S.; Xu, C.; Li, X.; et al. Natural variation in Ghd7 is an important regulator of heading date and yield potential in rice. Nat. Genet. 2008, 40, 761-767. [CrossRef]

109. Kim, H.W.; Kim, J.B.; Shanmugavelan, P.; Kim, S.N.; Cho, Y.S.; Kim, H.R.; Lee, J.T.; Jeon, W.T.; Lee, D.J. Evaluation of $\hat{\mathrm{I}}^{3}$-oryzanol content and composition from the grains of pigmented rice-germplasms by LC-DAD-ESI/MS. BMC Res. Notes 2013, 6, 149. [CrossRef]

110. Jiang, W.; Struik, P.C.; Lingna, J.; Van, K.H.; Zhao, M.; Stomph, T.J. Uptake and distribution of root-applied or foliar applied 65Zn after flowering in aerobic rice. Ann. Appl. Biol. 2007, 150, 383-391. [CrossRef]

111. Anuradha, K.; Agarwal, S.; Rao, Y.V.; Rao, K.V.; Viraktamath, B.C.; Sarla, N. Mapping QTLs and candidate genes for iron and zinc concentrations in unpolished rice of Madhukar $\times$ Swarna RILs. Gene 2012, 508, 233-240. [CrossRef] [PubMed]

112. Xu, Q.; Zheng, T.Q.; Hu, X.; Cheng, L.R.; Xu, J.L.; Shi, Y.M. Examining two sets of introgression lines in rice (Oryza sativa L.) reveals favorable alleles that improve grain Zn and Fe concentrations. PLoS ONE 2015, 10, e0131846. [CrossRef] [PubMed]

113. Counce, P.A.; Siebenmorgen, T.J.; Poag, M.A.; Holloway, G.E.; Kocher, M.F.; Lu, R. Panicle emergence of tiller types and grain yield of tiller order for direct-seeded rice cultivars. Field Crops Res. 1996, 47, $235-242$. [CrossRef]

114. Kuroda, E.; Abe, S.; Ishibashi, F.; Hirano, M.; Murata, T. Varietal difference in the relationship between the number of panicles per hill and the number of spikelets per panicle on the main stems and on primary and secondary tillers of rice. Jpn. J. Crop Sci. 1999, 68, 385-389. [CrossRef]

115. Zhang, B.; Yamagishi, J. Response of spikelet number per panicle in rice cultivars to three transplanting densities. Plant Prod. Sci. 2010, 13, 279-288. [CrossRef]

116. Kato, T. Effects of the shading and rachis-branch clipping on the grain-filling process of rice cultivars differing in the grain size. Jpn. J. Crop Sci. 1986, 55, 252-260. [CrossRef] 
117. Reddy, S.P.; Reddy, B.V.S.; Kumar, A.A.; Ramesh, S.; Sahrawat, K.L.; Rao, P.V. Association of Grain Fe and Zn Contents with Agronomic Traits in Sorghum. Indian J. Plant Genet. Res. 2010, 23, 280-284.

118. Rahul, T.; Khandkar, U.R.; Nath, D.; Patidar, RK.; Patidar, N.K. Documentation on Enhancing Nutrient Uptake and Yield of Rice with Application of Sewage Sludge and Different Fertility Levels on Sodic Vertisols. Int. J. Curr. Microbiol. Appl. Sci. 2017, 6, 2986-2998. [CrossRef]

119. Zhang, M.; Pinson, S.R.M.; Tarpley, L.; Huang, X.Y.; Lahner, B.; Yakubova, E.; Baxter, I.; Guerinot, M.L.; Salt, D.E. Mapping and validation of quantitative trait loci associated with concentrations of 16 elements in unmilled rice grain. Theor. Appl. Genet. 2014, 127, 137-165. [CrossRef]

120. Zhang, J.; Chen, K.; Pang, Y.; Naveed, S.A.; Xiuqin, Z.; Wang, X.; Wang, Y.; Dingkuhn, M.; Pasuquin, J.; Li, Z.; et al. QTL mapping and candidate gene analysis of ferrous iron and zinc toxicity tolerance at seedling stage in rice by genome-wide association study. BMC Genom. 2017, 18, 828. [CrossRef] [PubMed]

121. Collard, B.C.Y.; Mackill, D.J. Marker-assisted selection: An approach for precision plant breeding in the twenty-first century. Philos. Trans. R. Soc. B 2007, 363, 557-572. [CrossRef] [PubMed]

122. Chen, H.; Xie, W.; He, H.; Yu, H.; Chen, W.; Li, J.; Yu, R.; Yao, Y.; Zhang, W.; He, Y.; et al. A high-density SNP genotyping array for rice biology and molecular breeding. Mol. Plant 2014, 7, 541-553. [CrossRef] [PubMed]

123. Chang, L.Y.; Toghiani, S.; Ling, A.; Aggrey, S.E.; Rekaya, R. High density marker panels, SNPs prioritizing and accuracy of genomic selection. BMC Genet. 2018, 19, 4. [CrossRef]

124. Pritchard, J.; Stephens, M.; Donnelly, P. Inference of population structure using multilocus genotype data. Genetics 2002, 155, 945-959.

125. Stich, B.; Mohring, J.; Piepho, H.; Heckenberger, M.; Buckler, E.S.; Melchinger, A.E. Comparison of mixed-model approaches for association mapping. Genetics 2008, 178, 1745-1754. [CrossRef] [PubMed]

126. Norton, G.J.; Douglas, A.; Lahner, B.; Yakubova, E.; Gueirnot, M.L.; Pinson, S.R.M. Genome wide association mapping of grain arsenic, copper, molybdenum and zinc in rice (Oryza sativa L.) grown at four international field sites. PLoS ONE 2014, 9, e89685. [CrossRef]

127. Nawaz, Z.; Kakar, K.U.; Li, X.B.; Li, S.; Zhang, B.; Shou, H.X. Genome-wide association mapping of quantitative trait loci (QTLs) for contents of eight elements in brown rice (Oryza sativa L.). J. Agric. Food Chem. 2015, 63, 8008-8016. [CrossRef]

128. Nordborg, M.; Tavaré, S. Linkage disequilibrium: What history has to tell us. Trends Genet. 2002, 18, 83-90. [CrossRef]

129. Begum, H.; Spindel, J.E.; Lalusin, A.; Borromeo, T.; Gregorio, G.; Hernandez, J.; Virk, P.; Collard, B.; McCouch, S.R. Genome-Wide Association Mapping for Yield and Other Agronomic Traits in an Elite Breeding Population of Tropical Rice (Oryza sativa). PLoS ONE 2015, 10, e0119873. [CrossRef]

130. Spindel, J.; Begum, H.; Akdemir, D.; Virk, P.; Collard, B. Correction: Genomic Selection and Association Mapping in Rice (Oryza sativa): Effect of Trait Genetic Architecture, Training Population Composition, Marker Number and Statistical Model on Accuracy of Rice Genomic Selection in Elite, Tropical Rice Breeding Lines. PLoS Genet. 2015, 11, e1005350. [CrossRef]

131. Gregorio, G.; Senadhira, D.; Htut, H.; Graham, R.D. Breeding for trace mineral density in rice. Food Nutr. Bull. 2000, 21, 382-386. [CrossRef]

132. Hittalmani, S.; Huang, N.; Courtois, B.; Venuprasad, R.; Shashidhar, H.E.; Zhuang, J.Y.; Zheng, K.L.; Liu, G.F.; Wang, G.C.; Sidhu, J.S.; et al. Identification of QTL for growth- and grain yield-related traits in rice across nine locations of Asia. Theor. Appl. Genet. 2003, 107, 679-690. [CrossRef] [PubMed]

133. Qiao, Y.; Piao, R.; Shi, J.; Lee, S.I.; Jiang, W. Fine mapping and candidate gene analysis of dense and erect panicle 3, DEP3, which confers high grain yield in rice (Oryza sativa L.). Theor. Appl. Genet. 2011, 122, 1439-1449. [CrossRef] [PubMed]

134. Norton, G.J.; Deacon, C.M.; Xiong, L.; Huang, S.; Meharg, A.A.; Price, A.H. Genetic mapping of the rice ionome in leaves and grain: Identification of QTLs for 17 elements including arsenic, cadmium, iron and selenium. Plant Soil 2010, 329, 139-153. [CrossRef]

135. Swamy, B.P.M.; Vikram, P.; Dixit, S.; Ahmed, H.U.; Kumar, A. Meta-analysis of grain yield QTL identified during agricultural drought in grasses showed consensus. BMC Genom. 2011, 12, 319. [CrossRef] [PubMed]

136. Liu, E.; Liu, Y.; Wu, G.; Zeng, S.; Tran Thi, T.G.; Liang, L.; Liang, Y.; Dong, Z.; She, D.; Wang, H.; et al. Identification of a candidate gene for panicle length in rice (Oryza sativa L.) via association and linkage analysis. Front. Plant Sci. 2016, 7, 596. [CrossRef] [PubMed] 
137. Sun, Z.Z.; Yin, X.L.; Ding, J.; Yu, D.; Hu, M.; Sun, X.M.; Tan, Y.N.; Sheng, X.B.; Liu, L.; Mo, Y.; et al. QTL analysis and dissection of panicle components in rice using advanced backcross populations derived from Oryza sativa cultivars HR1128 and 'Nipponbare'. PLoS ONE 2017, 12, e0175692. [CrossRef]

138. Ying, J.Z.; Chen, Y.Y.; Zhang, H.W. Functional Characterization of Genes/QTLs for Increasing Rice Yield Potential. IntechOpen 2014. [CrossRef]

139. Li, H.; Lian, C.; Zhang, Z.; Shi, X.; Zhang, Y. Agro-biofortification of iron and zinc in edible crops for the global South. Adv. Plants Agric. Res. 2017, 6, 52-54.

140. Liang, Z.; Wang, L.; Pan, Q. A New Recessive Gene Conferring Resistance Against Rice Blast. Rice 2016, 9, 47. [CrossRef] [PubMed]

141. McCouch, S.R.; Wright, M.H.; Tung, C.W.; Maron, L.G.; McNally, K.L.; Fitzgerald, M.; Singh, N.; DeClerck, G.; Perez, F.A.; Korniliev, P.; et al. Open access resources for genome-wide association mapping in rice. Nat. Commun. 2016, 7, 10532. [CrossRef] [PubMed]

142. Bargsten, J.W.; Nap, J.P.; Sanchez-Perez, G.F.; Dijk, A.D.J. Prioritization of candidate genes in QTL regions based on associations between traits and biological processes. BMC Plant Biol. 2014, 14, 330. [CrossRef]

143. Lau, W.C.; Rafii, M.Y.; Ismail, M.R.; Puteh, A.; Latif, M.A.; Ramli, A. Review of functional markers for improving cooking, eating, and the nutritional qualities of rice. Front. Plant Sci. 2015, 6, 832. [CrossRef] [PubMed]

144. Jegadeesan, R.; Palanisamy, S.; Ganesh, A.; Ramasamy, S.; Ranganathan, C. Functional Marker Assisted Improvement of Stable Cytoplasmic Male Sterile Lines of Rice for Bacterial Blight Resistance. Front. Plant Sci. 2017, 8, 1131.

145. Taoka, K.-I.; Ohki, I.; Tsuji, H.; Furuita, K.; Hayashi, K.; Yanase, T.; Yamaguchi, M.; Nakashima, C.; Purwestri, Y.A.; Tamaki, S.; et al. 14-3-3 proteins act as intracellular receptors for rice Hd3a florigen. Nature 2011, 476, 332-335. [CrossRef] [PubMed]

146. Bai, X.; Huang, Y.; Mao, D.; Wen, M.; Zhang, L.; Xing, Y. Regulatory role of FZP in the determination of panicle branching and spikelet formation in rice. Sci. Rep. 2016, 6, 19022. [CrossRef]

147. Kurata, N.; Miyoshi, K.; Nonomura, K.I.; Yamazaki, Y.; Ito, Y. Rice Mutants and Genes Related to Organ Development, Morphogenesis and Physiological Traits. Plant Cell Physiol. 2005, 46, 48-62. [CrossRef]

148. Sun, X.; Cao, Y.; Yang, Z.; Xu, C.; Li, X.; Wang, S.; Zhang, Q. Xa26, a gene conferring resistance to Xanthomonas oryzae pv. oryzae in rice, encodes an LRR receptor kinase-like protein. Plant J. 2004, 37, 517-527.

149. Xiang, Y.; Cao, Y.; Xu, C.; Li, X.; Wang, S. Xa3, conferring resistance for rice bacterial blight and encoding a receptor kinase-like protein, is the same as Xa26. Theor. Appl. Genet. 2006, 113, 1347-1355. [CrossRef]

150. Bossa-Castro, A.M.; Tekete, C.; Raghavan, C.; Delorean, E.E.; Dereeper, A.; Dagno, K.; Koita, O.; Mosquera, G.; Leung, H.; Verdier, V.; et al. Allelic variation for broad-spectrum resistance and susceptibility to bacterial pathogens identified in a rice MAGIC population. Plant Biotechnol. J. 2018, 16, 1559-1568. [CrossRef] [PubMed]

151. Gnanamanickam, S.; Brindha Priyadarisini, V.; Narayanan, N.; Vasudevan, P.; Kavitha, S. An overview of bacterial blight disease of rice and strategies for its management. Curr. Sci. 1999, 77, 1435-1443.

152. Ashikawa, I.; Hayashi, N.; Yamane, H.; Kanamori, H.; Wu, J.; Matsumoto, T.; Ono, K.; Yano, M. Two adjacent nucleotide-binding site-leucine-rich repeat class genes are required to confer Pikm-specific rice blast resistance. Genetics 2008, 180, 2267-2276. [CrossRef] [PubMed]

153. Yuan, B.; Zhai, C.; Wang, W.; Zeng, X.; Xu, X.; Hu, H.; Lin, F.; Wang, L.; Pan, Q. The Pik-p resistance to Magnaporthe oryzae in rice is mediated by a pair of closely linked CC-NBS-LRR genes. Theor. Appl. Genet. 2011, 122, 1017-1028. [CrossRef] [PubMed]

154. Zhai, C.; Lin, F.; Dong, Z.; He, X.; Yuan, B.; Zeng, X.; Wang, L.; Pan, Q. The isolation and characterization of $P i k$, a rice blast resistance gene which emerged after rice domestication. New Phytol. 2011, 189, 321-334. [CrossRef]

(C) 2019 by the authors. Licensee MDPI, Basel, Switzerland. This article is an open access article distributed under the terms and conditions of the Creative Commons Attribution (CC BY) license (http:/ / creativecommons.org/licenses/by/4.0/). 